\title{
Paleontology to policy: the Quaternary history of Southeast Asian tapirs (Tapiridae) in relation to large mammal species turnover, with a proposal for conservation of Malayan tapir by reintroduction to Borneo
}

\author{
Earl of CRANBROOK ${ }^{1}$ and Philip J. PIPER ${ }^{2,3}$ \\ ${ }^{1}$ Great Glemham House, Saxmundham, UK, ${ }^{2}$ School of Archaeology and Anthropology, Australian National University, Canberra, \\ Australia and ${ }^{3}$ Archaeological Studies Program, Palma Hall, Diliman 1101, Quezon City, Philippines
}

\begin{abstract}
The Southeast Asian zoogeographical region is divided into Indochinese, Sundaic and Philippine subregions. Two clades of tapirs, Tapirus spp., have been recognized in Quaternary Southeast Asia. A review of sites at which they occurred shows that representatives of both clades, one of which was the ancestral Malayan tapir Tapirus indicus, co-existed with a diversity of other Pleistocene mammal megafauna. The process of replacement of archaic large mammals was progressive and prolonged through the Quaternary. Zooarcheological investigation has extended knowledge of the former occurrence and distribution of tapirs and other large mammals of the region, with discoveries beyond the outer limits of their previously known ranges. These large mammals were subjected to paleoenvironmental changes as a consequence of the Quaternary cycles of glacial and interglacial periods. Archeological evidence suggests that hunting pressure has intensified the effects of altered environments, leading ultimately to the local disappearance of the Malayan tapir in most of Southeast Asia, including Borneo. The survival of the Malayan tapir through the Quaternary until the present shows that the species is both resilient to environmental change and flexible in its ecological requirements and, given proper protection, could continue to inhabit tropical Southeast Asia. To assist the species' conservation, reintroduction is proposed from the remaining range of Malayan tapir in the wild, to suitable sites of past occurrence in Borneo, where these ancient survivors of the Quaternary megafauna can be accommodated and safeguarded alongside other forms of land usage.
\end{abstract}

Key words: extinction, large mammals, Pleistocene, reintroduction, tapir

Correspondence: Lord Cranbrook, Great Glemham House,

Saxmundham IP17 1LP, UK.

Email: lordcranbrook@greatglemhamfarms.co.uk

\section{CONVENTIONS}

The term 'megafauna' is customarily defined as animals exceeding $44 \mathrm{~kg}$ weight. In this review, consideration is given to a wider group weighing over $6 \mathrm{~kg}$, col- 
lectively referred to as 'large mammals', with members principally among the orders Primates, Carnivora, Proboscidea, Perissodactyla and Artiodactyla. Systematic names are given with vernacular names at first mention, thereafter, if the identity is clear in context, the vernacular name is used alone. In summarizing paleontological and archeological records, apart from updating some generic names in accordance with current opinion, taxonomic identities have not been reassessed and the nomenclature of source references has been followed. To denote an extinct taxon, the symbol $\dagger$ is placed to the left of the genus, species or subspecies name, as applicable. Chinese place names are in Pinyin; however, in some instances, for clarity, the alternative WadeGiles transcription system is also given. For brevity, the term(s) Southeast Asia(n) and Island Southeast Asia(n) are abbreviated to SEA and ISEA, respectively. ISEA refers to Sumatra, Java, Borneo, Palawan and other islands located on the Sunda shelf and within the Sundaic biogeographic region, to distinguish these from the Wallacean islands to the east. Other conventional abbrevia- tions used are: LGP, last glacial period; LGM, last glacial maximum; kyr, thousand years; Myr, million years; $\mathrm{ka}$, thousand years ago; and Ma, million years ago.

\section{INTRODUCTION}

\section{Southeast Asian regional zoogeography}

The zoogeographic region of SEA was defined by Corbet and Hill (1992) as the combination of 3 Indomalayan subregions: Indochinese with southern China $(\mathrm{C} 1$, C2), Sundaic including Palawan (D1-D5, D6) and Philippines (E) (Fig. 1). In political terms, the region comprises Bangladesh, northeastern India, southern China, Burma (Myanmar), Thailand, Laos, Cambodia, Vietnam, Malaysia, Singapore, Brunei, Indonesia west of Wallace's Line and the Philippines. Among living mammals, the region is characterized by many tropical forest genera and species that do not extend into India, or to temperate China where, since the Early Pleistocene, the Qinling mountain range in Shaanxi province has formed
Figure 1 The zoogeographic region of Southeast Asia, subdivided into subregions (C) Indochinese, (D) Sundaic, with Palawan and (E) Philippines; adapted from Corbet and Hill (1992). (F) Wallacea is not treated in this review.

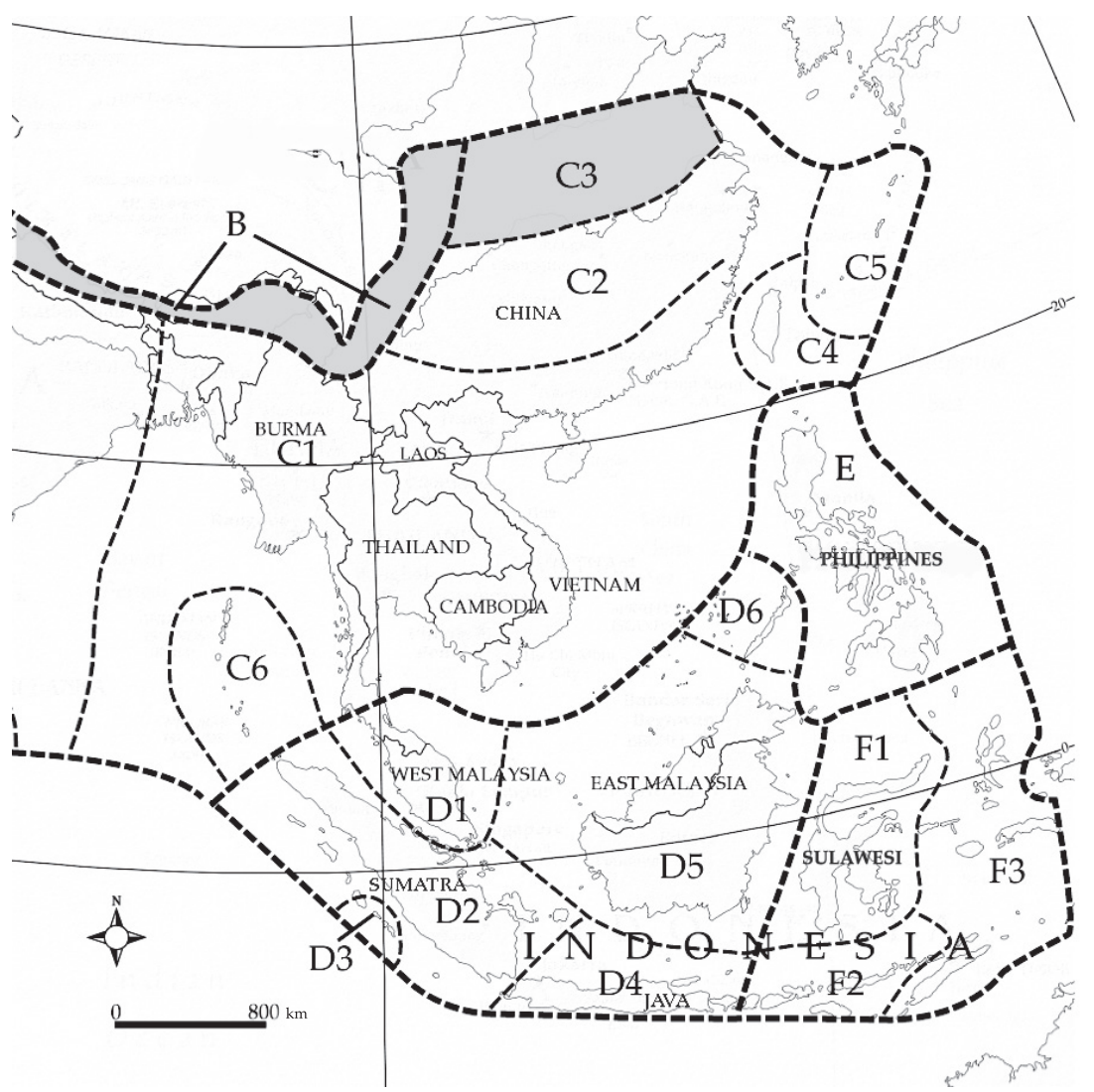


the zoogeographic boundary separating eastern Palearctic and Indomalayan faunas (Rink et al. 2008). At the subregional level, there is an important boundary in the Thai-Malay peninsula defining the continental limit of a distinctive Sundaic fauna that includes several endemic genera and many endemic species. Of the 3 Greater Sunda Islands, Sumatra supports the most diverse mammal fauna, with many genus-level taxa shared with Peninsular Malaysia, while that of Java is disproportionately depleted. Borneo has a rich mammal fauna of 239 known species, among which 50 of 136 terrestrial species (i.e. excluding bats) are endemic, including 3 endemic genera. The mammal community of Palawan consists of 62 species, of which 13 are endemic. Although species-poor by comparison with Borneo, this fauna includes characteristic Sundaic mammalian genera which do not occur naturally elsewhere in the Philippines (Heaney 1985; Esselstyn et al. 2004).

\section{Origin, distribution and nomenclature of tapirs}

The first tapir, family Tapiridae, appeared in the Oligocene, as the extinct genus $\dagger$ Protapirus, occurring through North America and Europe. In the Late Pliocene, tapirs extended from South America to eastern Asia (as Tapirus, in Romer 1966). Worldwide, there are now 4 living species. Three occur in Central and South America and 1, the Malayan tapir, is the sole representative of the family in SEA. A combination of anatomical features and molecular divergence indicates that the American tapirs form a clade distinct from the Malayan tapir, with the split at about $18 \mathrm{Ma}$ and a further separation among the American species at about $3 \mathrm{Ma}$. Groves and Grubb (2011) have reflected this evidence in generic nomenclature, with 2 American species in Tapir$u s$ and the third in Tapirella. The available generic-level name for the Asian clade is Acrocodia, yielding Acrocodia indica (Desmarest, 1819) as the systematic name for the Malayan tapir. While noting this opinion, the present review follows the earlier classification of the late Peter Grubb (2005), who placed all 4 living tapir species in the single genus Tapirus with the Malayan tapir Tapirus indicus Desmarest, 1819. This generic usage has been current for many years in paleontological literature and, since retrospective amendment of many historical references would be potentially confusing, this terminology has been retained.

\section{The Quaternary period and megafauna extinctions}

The Quaternary geological period began with the Pliocene-Pleistocene transition, dated by the International
Union of Geological Sciences (IUGS) at 2.588 Ma and is divided into the Early, Middle and Late Pleistocene epochs followed by the present Holocene, beginning about $11 \mathrm{ka}$. During the Quaternary, global climatic fluctuations had profound environmental impacts, worldwide, as 'glacial' periods of lowered average ambient temperature alternated with briefer, warm 'interglacial' periods. From the mid-Middle Pleistocene (about 500 ka) successive glacial periods each lasted around 100 kyr, separated by interglacials of $\sim 15$ kyr. During glacial periods, polar ice sheets enlarged and high altitude glaciers expanded, sequestering large volumes of the world's finite supply of surface water so that global sealevels fell. Worldwide, fluctuations in climate had the effect of altering the vertical and horizontal distribution of ecological communities, with expansions and contractions dependent on the locally prevailing environmental conditions. Large mammals may be particularly vulnerable to the changing availability of resources, periodically resulting in total or local extinction events, sometimes succeeded by expansion and re-colonization. A widespread loss of large mammal species at the close of the Pleistocene epoch has been termed the 'Quaternary megafauna extinctions' (Martin \& Klein 1984). Beginning about $50 \mathrm{ka}$, by the close of the episode at $\sim 7 \mathrm{ka}$ at least 101 mammalian genera became extinct worldwide. Extinction intensity varied by continent; the hardest hit being Australia losing $88 \%$ of megafauna genera, South America $83 \%$ and North America $72 \%$. The least affected was Eurasia, which, as a whole, lost only $35 \%$ of its megafauna mammal genera: 4 globally extinct, 5 extinct on the continent, 17 surviving (Corlett 2010). Molecular data have provided additional insights into the phylogeny of regional taxa and the timing of past divergences (e.g. Lucchini et al. 2005). Authors including Tougard (1998), van den Bergh et al. (2001), Louys et al. (2007), Corlett (2010) and Louys and Meijaard (2010) have reviewed SEA regional megafauna extinctions and debated the nature and variety of causes.

The paleogeography and paleoecology of SEA were strongly affected by the glacial cycles, notably in the Sundaic biogeographic subregion. In the shallow seas of the Sunda shelf, Quaternary marine recessions during glacial periods extended shorelines and exposed the seabed, thereby providing links between the present islands and with the continent. At glacial peaks, lowered ambient temperature and decreased rainfall impacted adversely on forest habitat. The last interglacial, $\sim 126-115$ ka was followed by the LGP which culminated at the LGM, 23-18 ka, when average global ambient air tem- 
peratures fell to around $5{ }^{\circ} \mathrm{C}$ lower than present. The sea level dropped by $\sim 120 \mathrm{~m}$ below the present datum, exposing the entire Sunda Shelf as a huge terrain of subcontinental dimensions. Following this episode, as global temperatures began to increase, the sea level rose, slowly at first, with a rapid surge about $14 \mathrm{ka}$ and finally severed the land bridge between Sumatra and Borneo $\sim 10 \mathrm{ka}$ (Bird et al. 2005; Cannon et al. 2009; Cranbrook 2010).

Today's SEA regional geography is therefore untypical, representing an extreme state in the latest of a succession of interglacial episodes that may cumulatively amount to no more than $42 \mathrm{kyr}$ or $2 \%$ of the Quaternary period (Woodruff 2010). The depressed sea level that has been the norm throughout most of this period permitted migration, colonization, and exchange of species between the continent and the islands of Southeast Asia. Hence, the majority of plants and animals of the Sundaic subregion have a shared derivation from continental SEA, supplemented by regional radiation (Darlington 1957). Yet, as Darlington (1957) also noted, in their present occurrence some conspicuous members of the widespread SEA regional large mammal fauna are absent from Borneo: dhole or serigala Cuon alpinus (Pallas, 1811), tiger Panthera tigris (Linnaeus, 1758), leopard Panthera pardus (Linnaeus, 1758), Javan rhinoceros Rhinoceros sondaicus Desmarest, 1822, Malayan tapir and serow Capricornis sumatraensis (Bechstein, 1899). It is an achievement of archeology that some of these anomalous distributions have been shown since to be the consequence of Quaternary or recent extinctions.

\section{The Quaternary history of tapirs}

Given adequate comparative reference specimens, tapirs are readily recognizable in paleontological or zooarcheological contexts. The dentition is sufficiently distinctive that confident identification can be based on a single tooth or an isolated crown (Fig. 2). The foot skeleton is peculiar, with 4 toes on the fore feet and 3 on the hind feet. Small foot bones survive well as fossils and are therefore useful identifiers of tapir among the skeletal remains of other large mammals (Fig. 3). The identification of tapirs in the paleontological and archeological record in SEA has been fundamental in determining the past presence, timings of appearance and extinction of members of the family in association with diverse faunal communities. The representation of Tapiridae at paleontological sites, summarized below from published sources, identifies 2 clades coexisting at the outset of the Quaternary. By the close of the period, 1 lineage had be- come extinct while, of the other, 1 representative species survived: the Malayan tapir. In combination, paleontological and zooarcheological records show that the Malayan tapir is an ancient species that has existed within SEA for at least $1 \mathrm{Myr}$.

There have been a few reports in historic times of Malayan tapir from southern Vietnam, Cambodia and Laos (Grubb 2005). From the mid- $20^{\text {th }}$ century, however, its range has been restricted to Sumatra and Peninsular Malaysia (Chasen 1940), southeastern Burma in the "evergreen forests of Tenasserim from $18^{\circ} \mathrm{N}$ southwards" (Tun Yin 1967, p. 148) and adjacent parts of southwestern and peninsular Thailand (Lekagul \& McNeely 1977; Fig. 4). It is therefore evident that the con-

a

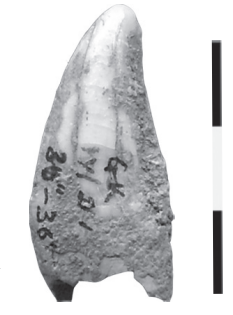

b
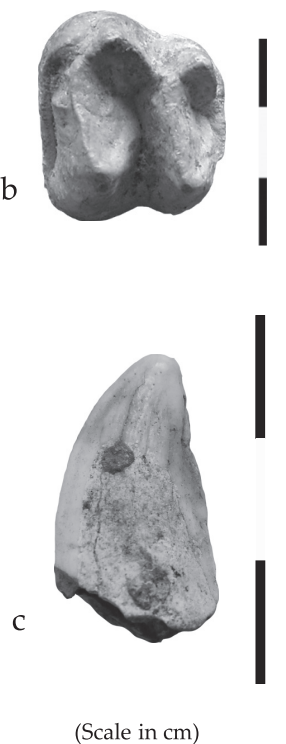

Figure 2 Archeological specimens of Malayan tapir from Sarawak, Malaysian Borneo: a partially erupted left mandibular canine (No. 5 in Table 2), the crown of a, partially erupted left 1 st maxillary molar (No. 6 in Table 2); b, both from the Gan Kira mouth of Niah Cave; and c, a partially erupted (right) mandibular canine from Gua Sireh (No. 3 in Table 2). 
traction and local extinction of Malayan tapirs within past geographic ranges has been relatively recent, mostly occurring within the last century. The 2012 IUCN Red List places Malayan tapir in the category 'endangered'.

A combination of archeological evidence and eye witness accounts combine to confirm that in Borneo, the disappearance of Malayan tapir is a recent occurrence. Proof of its historic presence in Borneo suggests that this surviving member of the Middle Pleistocene mam-

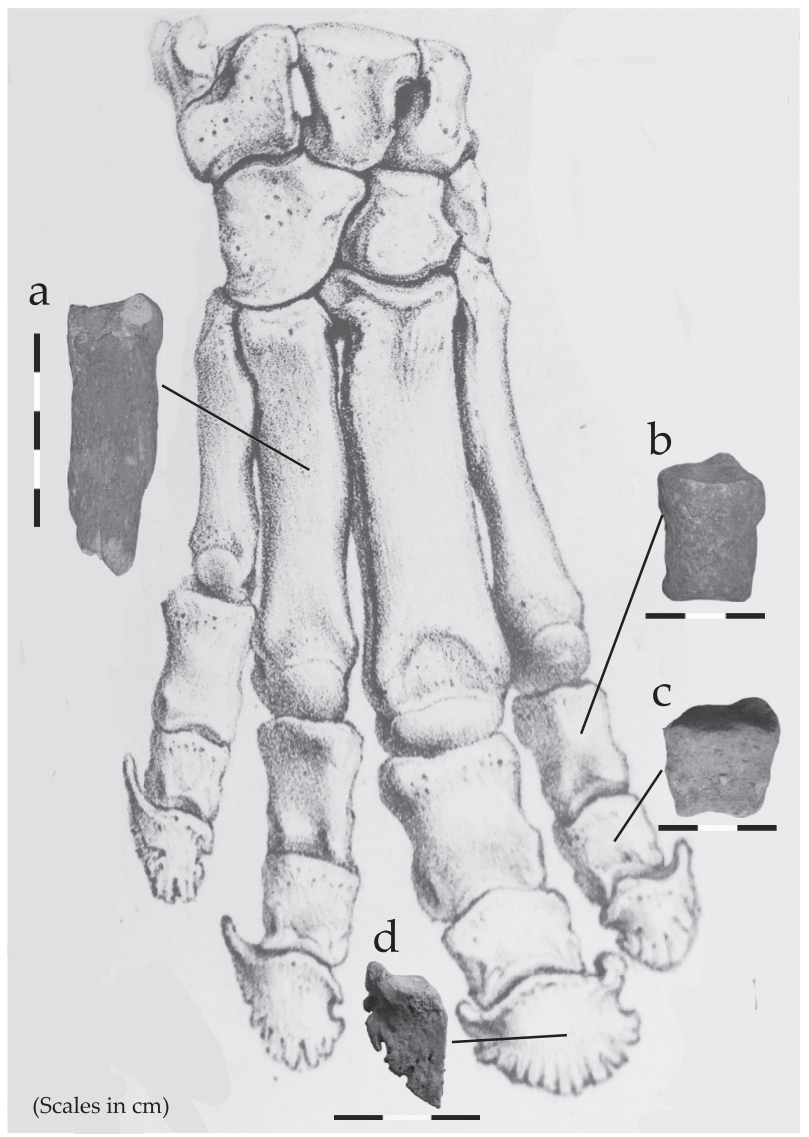

Figure 3 Skeleton of the right forefoot of Malayan tapir, adapted from de Blainville (1839-64), plate G. Tapirus IV, showing whole or partial elements that have been identified among zooarcheological specimens from cave sites in northwest and northern Borneo; a, proximal end of a metacarpal II or IV from Niah Cave West mouth (No. 6 in Table 3); b, basal phalanx II from Niah Cave West mouth (No. 13 in Table 3); c, right subterminal phalanx II of the manus from Cave V, Jambusan (No. 15 in Table 3); d, fragment of a terminal (ungual) phalanx digit III from Cave V, Jambusan (No. 17 in Table 3). mal megafauna was adapted to environments that exist on the island. It is therefore concluded that reintroduction of Malayan tapir to selected localities in Borneo by relevant agencies, within the national boundaries of Malaysia or Indonesia, is likely to succeed and may be important to aid the long term conservation and survival of this ancient species.

\section{TAPIRS AND QUATERNARY LARGE MAMMAL SPECIES TURNOVER}

\section{Early Pleistocene (2.58 Ma-778 ka)}

In southern Asia, a rich array of Neogene ( 23-2.59 Ma) and early Quaternary fossil sites occurs along the length of the Siwalik hills, fringing the southern Himalayas from Pakistan through India to Nepal and Burma. The geology is complex and a sequence of biostratigraphic zones is recognized (Nanda 2002). Among others, Hooijer (1952), Medway (1972), de Vos (1984), de Vos and Long (2001) and Patnaik and Nanda (2010) have drawn attention to genera or species common to the Siwalik formations and Early Pleistocene SEA fossil sites. Yet there are also significant differences between assemblages in the 2 regions, notably the absence of any record of tapir from the Siwalik group where other perissodactyls are well represented. Rather than direct contact, it is more likely that, along with genera and species of other origins (including local radiations contained within geographic or climatic barriers), both the Early Pleistocene faunas included members from a shared central Asian source. Such a source may have been the vast grasslands extending from south Asia to north China during this period (Dennell 2009), which facilitated movements of large grazing mammals over the continent. Dennell and Roebroeks (2005) suggested the term 'savannastan' to express the immensity of these grasslands.

In Asia, an Early Pleistocene species Tapirus $\dagger$ sanyauensis Huang, 1991 occurred in southern Palearctic China. With progressive increase in size and showing some dental modifications, this was succeeded by $\mathrm{Ta}$ pirus $\dagger$ sinensis Owen, 1870 of Early to Middle Pleistocene age, which in turn was ancestral to the largest form Tapirus (Megatapirus) †augustus (Matthew \& Granger, 1923) of the Middle to Late Pleistocene (Tong \& Xu 2001; Tong et al. 2002; Tong \& Liu 2004; Tong 2005). South of the Qinling range, a separate clade emerged in SEA identifiable as ancestral T. indicus, slightly larg- 


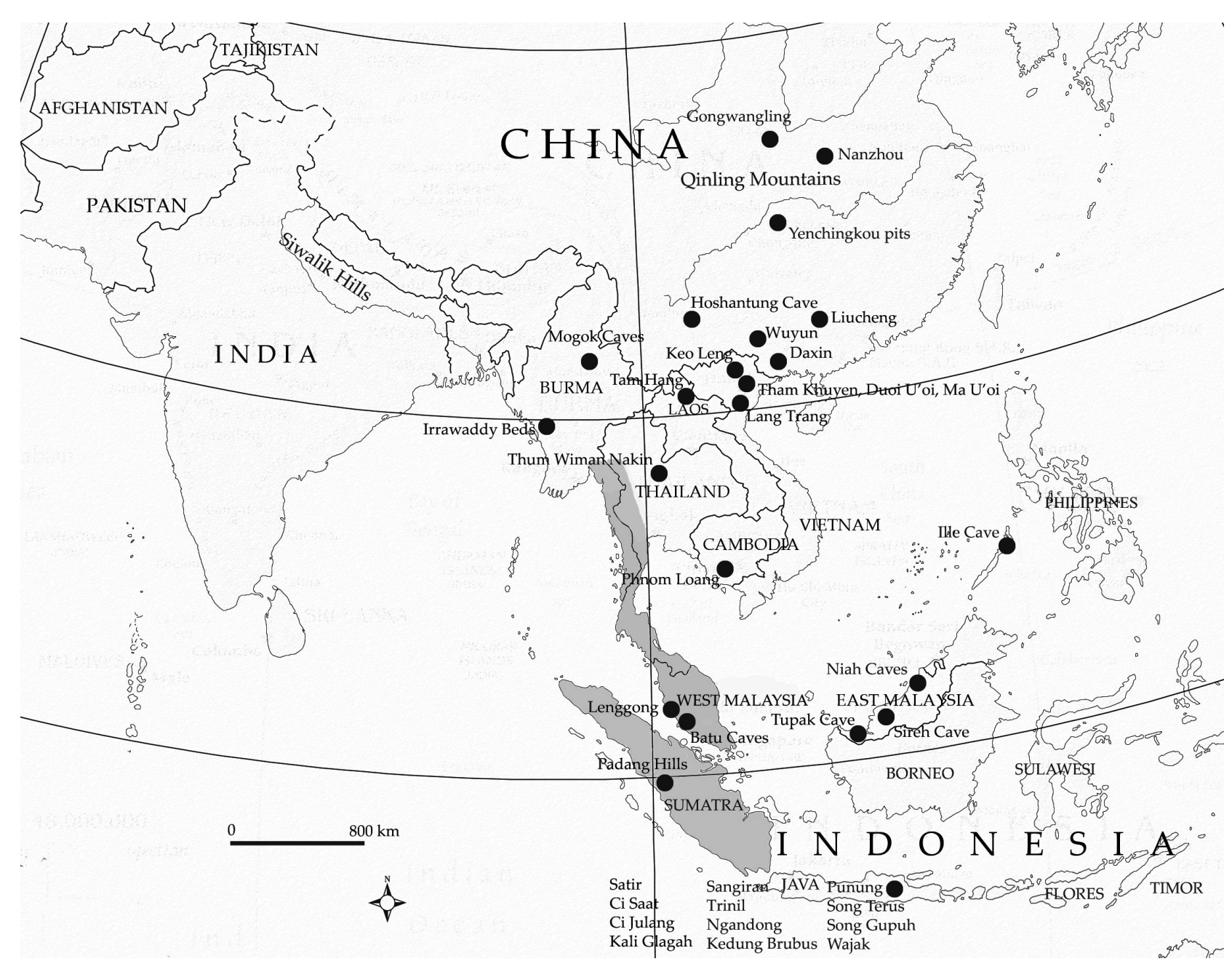

Figure 4 A map of South and Southeast Asia, showing locations (filled circles) mentioned in the text and (shaded area) the present distribution of the Malayan tapir (illustration by Piper \& Cranbrook). See text for full details.

er than Tapirus †sanyuanensis (Tong et al. 2002). Porosity of the Palaearctic/SEA zoogeographical boundary (Norton et al. 2010) is exemplified by the expansion of $T$. † sinensis into the Indochinese subregion, identified in Middle Pleistocene cave sites in Guangxi and Guangdong (Kahlke 1961).

Early Pleistocene tapirs co-existed in SEA with a mix of Tertiary genera or archaic species of modern genera of primates, carnivores, proboscideans, perissodactyls and artiodactyls. Notably, the fauna of southern China included some large mammals with Siwalik or Palearctic affinity atypical of SEA: wolf Canis, horse Equus and gazelle Gazella (Table 1). Early Pleistocene Ir- rawaddy beds of Burma also yielded horse and gazelle, with a mix of megafauna allied to the Siwalik mammals and an early appearance of modern SEA rhinoceros species (Table 1; Colbert 1943; Thien et al. 2006, 2010). The absence of tapirs at Irrawaddy sites sets a western limit to their Quaternary SEA distribution.

In the Sundaic subregion in the Early Pleistocene, some large mammals of Siwalik affinity were present in Java as components of a fauna termed 'SivaMalayan' (Hooijer 1952) found at Satir, Ci Saat, Ci Julang and Kali Glagah. Tapirs were not among this fauna, of which indicators were the widespread Quaternary hyena Hyaena (Pachycrocuta) †brevirostris Aymard, 


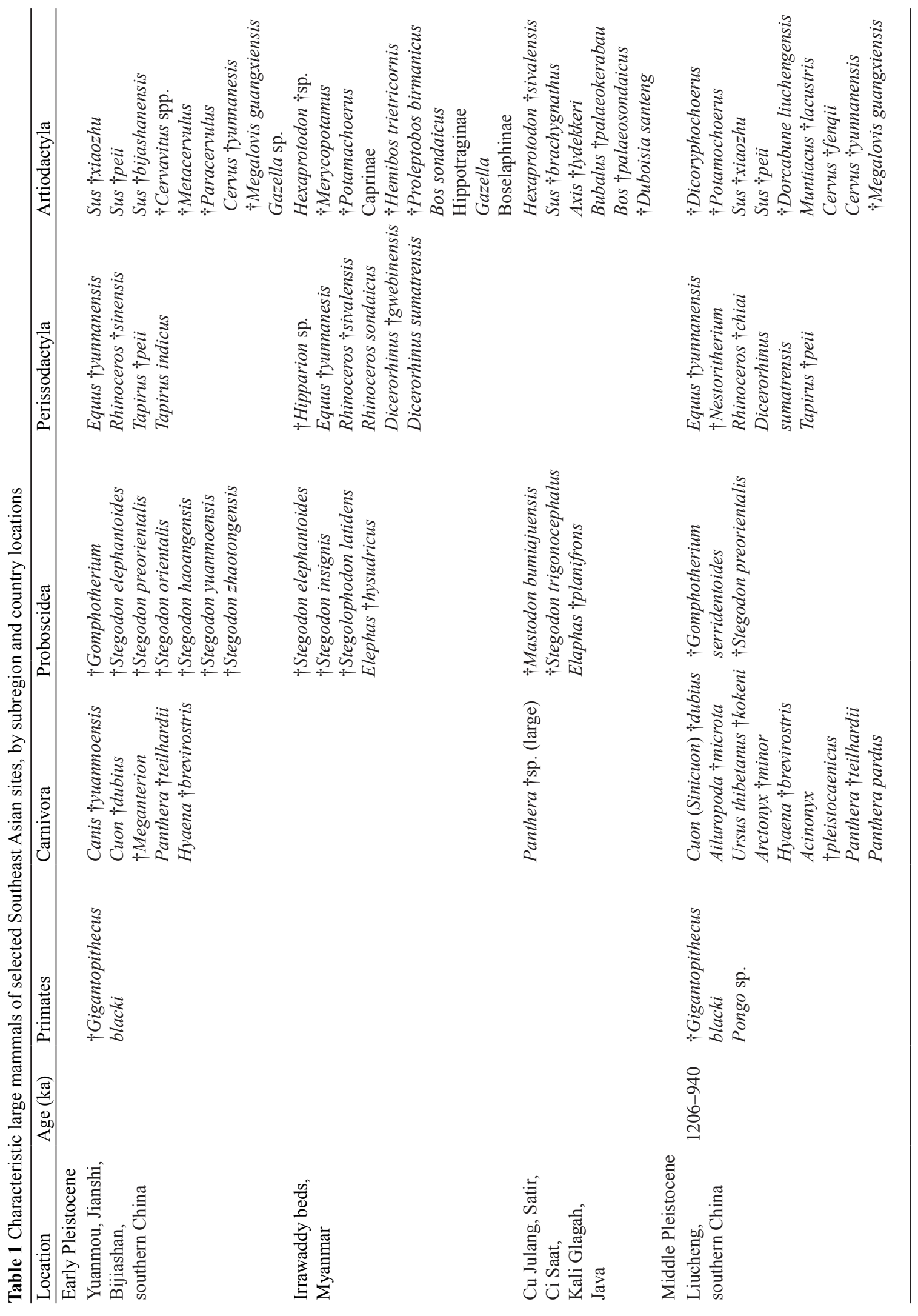




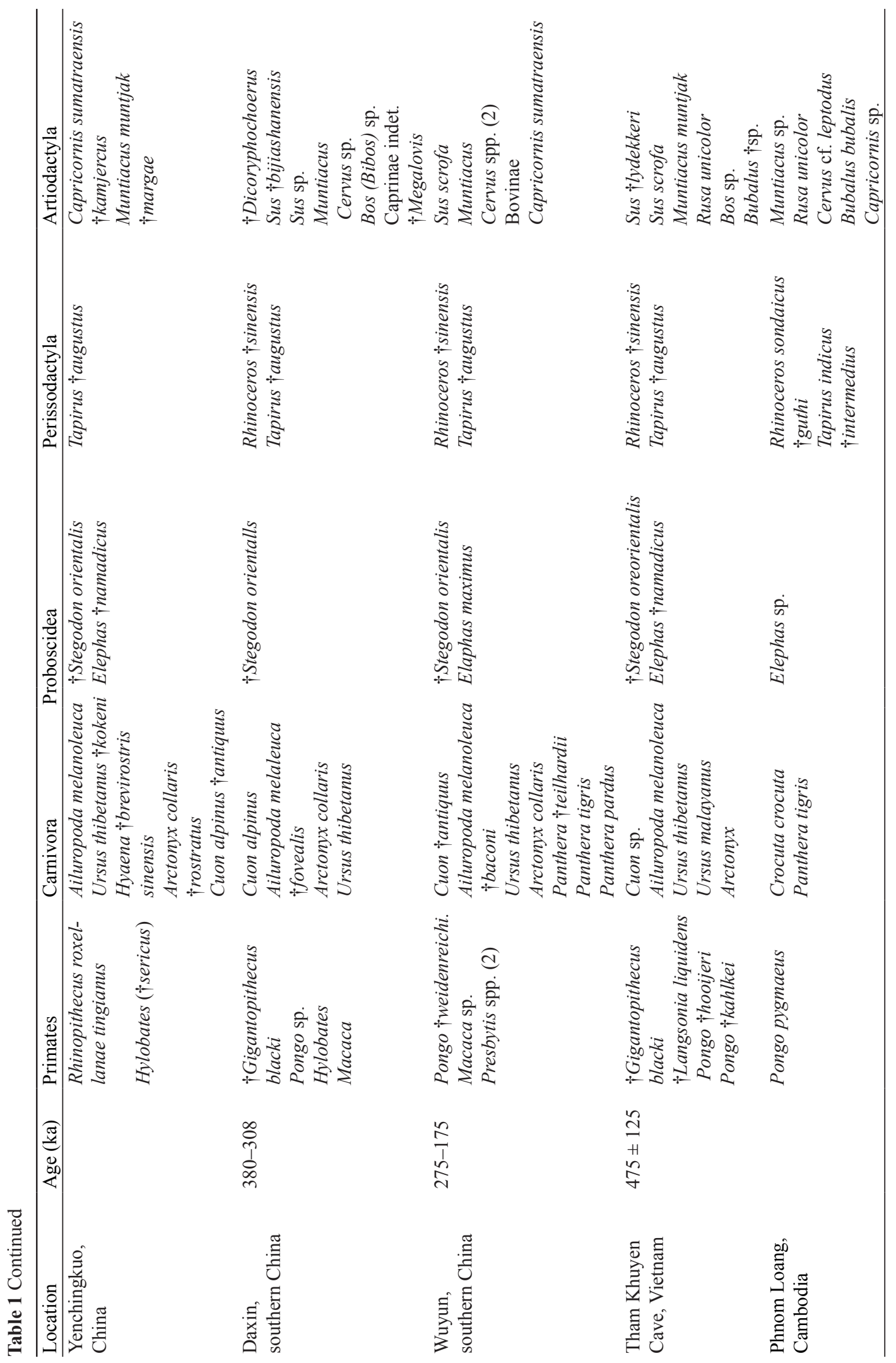




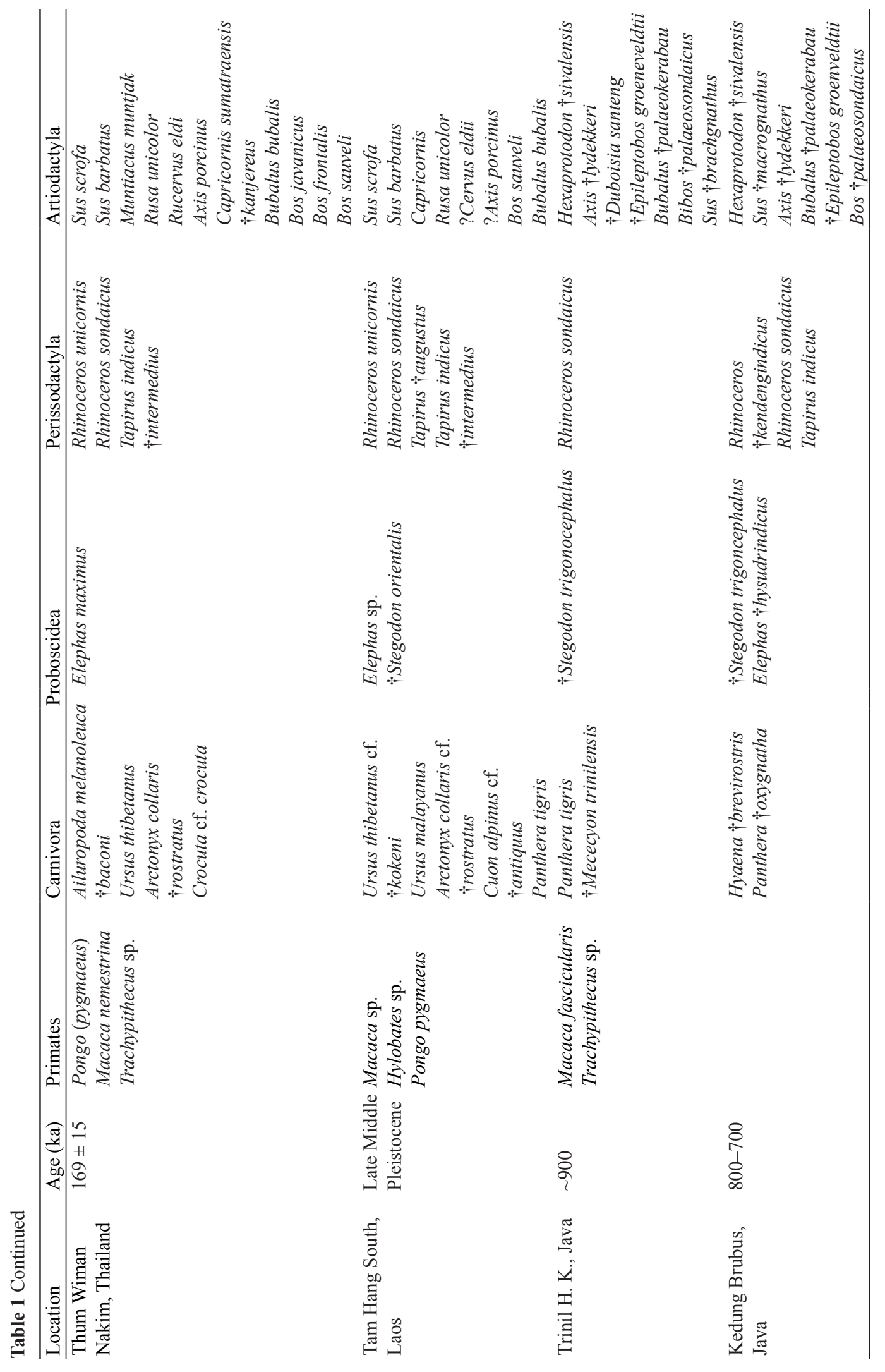




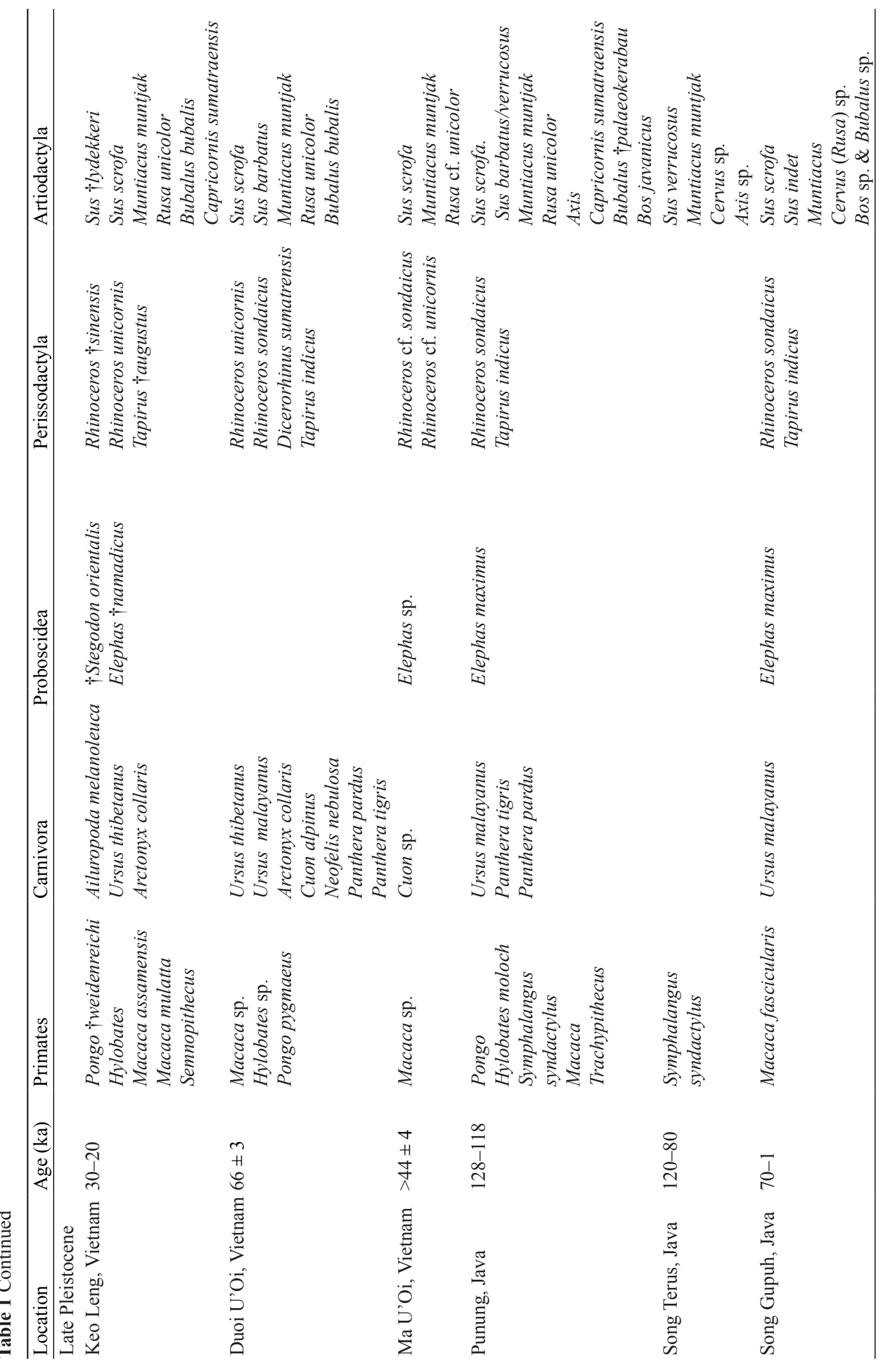




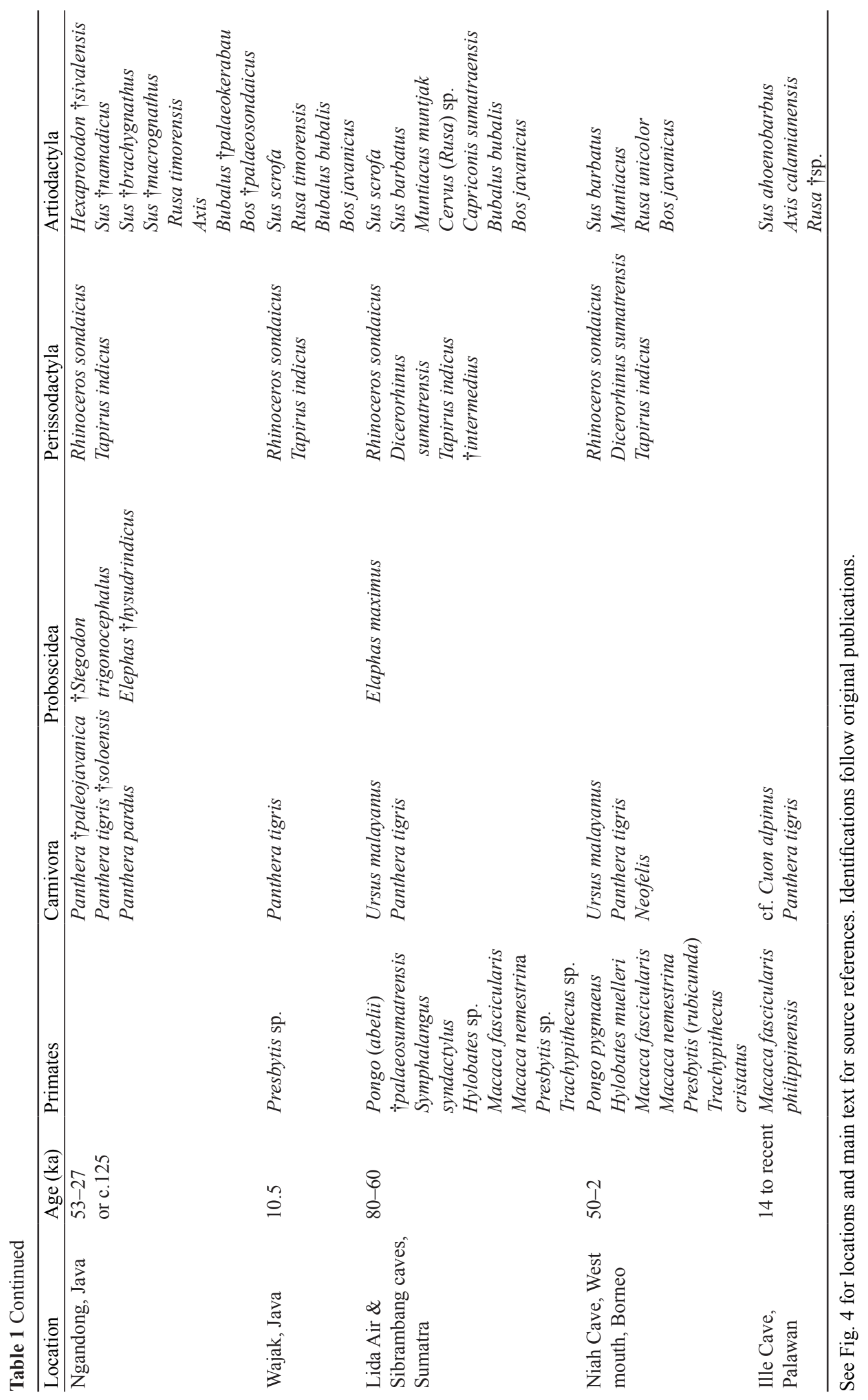


1846, the endemic stegodont $\uparrow$ Stegodon trigonocephalus Martin, 1887, primitive elephant Elephas †planifrons Falconer \& Cautley, 1845, Siwalik rhinoceros Rhinoceros $\dagger$ sivalensis Koken, 1885 and Siwalik hippopotamus Hexaprotodon $\dagger$ sivalensis Falconer \& Cautley, 1836 (Table 1; Medway 1972; Hooijer 1982; Louys et al. 2007). Mammal fossils of Early Pleistocene age are unknown elsewhere in the Sundaic subregion, but a single tooth of $\dagger$ Stegolophodon lydekkeri Osborn, 1936 obtained in northwestern Borneo in enigmatic circumstances would, if authentic, suggest connection with Plio-Pleistocene Burma where $\dagger$ Stegolophodon latidens (Lydekker, 1880) occurred (Cranbrook et al. 2007).

\section{Middle Pleistocene (778-126 ka)}

In the Middle Pleistocene a distinctive assemblage, termed the Stegodon-Ailuropoda fauna, expanded in the Indochinese subregion of SEA (Dennell 2009). Diagnostic members were an extinct large ape $\dagger$ Gigantopithecus blacki von Koenigswald, 1935, orangutans Pongo, giant pandas Ailuropoda and stegodonts $\dagger$ Stegodon spp. Associated faunas varied in composition and diversity, some containing archaic proboscidean genera such as $\dagger$ Mastodon and others recent genera such as $\mathrm{El}$ ephas. Bovine genera included archaic and modern cattle and buffalo and caprines were represented by the extant serow. Tapirs occurred at several sites, at different times and in different places in association with different communities of other large mammals (Table 1).

A transitional Early/Middle Pleistocene assemblage at Liucheng Gigantopithecus Cave in southern China (Fig. 4) included an archaic tapir Tapirus $\dagger$ peii Li, 1979 with $\dagger$ Gigantopithecus, orangutan, an archaic giant panda $\mathrm{Ai}$ luropoda $\uparrow$ microta Pei, 1963, $\uparrow$ Stegodon preorientalis Young, 1938, an extinct cheetah Acinonyx, dhole, hyena $H$. †brevirostris, Asiatic black bear Ursus thibetanus Cuvier, 1823, hog badger Arctonyx †minor Pei, 1987, large felids, a pachyderm $\dagger$ Gomphotherium, horse, Sumatran rhinoceros Dicerorhinus sumatrensis (Fischer, 1814) and a variety of pigs, barking deer, deer and a sheep †Megalovis (Table 1; Louys et al. 2007; Rink et al. 2008; Tong \& Guérin 2009). Dates derived by Rink et al. (2008) indicate an absolute age at Liucheng of about $1000 \mathrm{ka}$ (1206-940 ka, including uncertainties).

At Xinghau Shan, Nanzhau county, an enigmatic Middle Pleistocene record of 'giant' tapir $T$. $\dagger(M$. $) a u$ gustus was associated with grey wolf Canis lupus Linnaeus, 1758, tiger, Asiatic black bear, a horse Equus $\uparrow$ sanmeniensis Tielhard \& Piveteau, 1930, rhino Rhinoceros $\dagger$ sinensis and giant deer $\dagger$ Megaloceros (Dennell 2009). At other sites in southern China, dated biostratigraphically as Middle Pleistocene listed by Kahlke (1961), in Yunnan at Heshangdong (Hoshantung) Cave, at 3 sites in Sichuan, in Guangxi, Hubei and Guizhou, giant tapir occurred in association with $\dagger$ StegodonAiluropoda fauna. The Malayan tapir co-occurred with giant tapir at 1 site, confirming the separate identity of the 2 species. In Burma, at Mogok caves, giant panda Ailuropoda melanoleuca (David, 1869) was recorded, but not tapir, indicating the persistence of a western limit to the SEA distribution of the genus despite evident environmental change (Table 1).

A succession of chronometrically dated Middle Pleistocene sites in the Indochinese subregion shows progressive turnover in the large mammal faunas with which tapirs were associated (Fig. 4). At Tham Khuyen cave, Vietnam, $475 \pm 125 \mathrm{ka}$, the giant tapir occurred with a fauna including $\dagger$ Gigantopithecus, an enigmatic large hominoid known only from this cave $\dagger$ Langsonia liquidens Schwartz et al., 1995, 2 orangutans Pongo †hooijeri Schwartz et al., 1995 and Pongo †kahlkei Schwartz et al., 1995, a gibbon Hylobates, macaques, Asiatic black bear, sun bear Ursus (Helarctos) malayanus Raffles, 1821, giant panda, †Stegodon orientalis Owen, 1870, archaic forms of elephant, rhinoceros and pig (Table 1; Schwartz et al. 1995; Tougard 1998; Louys et al. 2007; Rink et al. 2008). At Daxin, southern China, 380-308 ka, the giant tapir was associated with $\dagger G i-$ gantopithecus, orangutan, macaque, dhole, Asian black bear, giant panda, hog badger, $\uparrow S$. orientaliis, pigs $\uparrow D i-$ coryphochoerus and Sus and modern genera and species of deer, cattle and an extinct sheep $\dagger$ Megalovis (Table 1; Tougard 1998; Rink et al. 2008). At Wuyun, southern China, 275-175 ka, tapirs were present with archaic subspecies of orangutan and giant panda, $\dagger$ S. orientalis and a mix of modern genera (Table 1; Schwartz et al. 1995; Rink et al. 2008). At Thum Wiman Nakim (Cave of the Sacred Serpent), Thailand, calcified clay sediments dated at $169 \pm 11 \mathrm{ka}$ immediately above the fossiliferous stratum set a minimum age for the assemblage (Bacon et al. 2011). Malayan tapir was present, with orangutan and giant panda and a near-modern fauna represented in some instances by extinct chrono-subspecies: pig-tailed macaque Macaca nemestrina (Linnaeus, 1766), langur, hyena, Asian black bear, hog-badger, Asian elephant, Indian rhinoceros Rhinoceros unicornis Linnaeus, 1758 and Javan rhinoceros Rhinoceros sondaicus Desmarest, 1822, Eurasian wild pig Sus scro- 
fa Linnaeus, 1758 and bearded pig Sus barbatus Müller, 1838, 3 cattle, buffalo, serow, muntjac Muntiacus and 3 deer (Table 1; Tougard 1998). At Tam Hang S. cave, Laos, giant tapir and Malayan tapir co-occured (Bacon et al. 2011).

Neither $\dagger$ Gigantopithecus nor giant panda reached the Sundaic subregion, where the equivalent Middle Pleistocene fauna of Java, termed 'Sino-Malayan' (Hooijer 1952), was indicated by orangutan Pongo and additional immigrants from the SEA continental mainland supplementing the more ancient Siva-Malayan fauna, plus the products of local radiation, notably $\dagger S$. trigonocephalus, archaic bovids and Dubois's antelope $\uparrow$ Duboisia santeng (Dubois, 1891) (Dubois 1908). Among chronometrically dated faunas, at $\sim 900$ ka the transitional early Middle Pleistocene assemblage at Trinil H. K. lacked tapir, but included modern primate genera, with an archaic tiger, archaic dog, $\uparrow$ S. trigonocephalus, Javan rhino, archaic pigs, chital, cattle and buffalo. Tapir remains were found in the later Kedung Brubus site, 800-700 ka. The Kedung Brubus specimens were described by Dubois (1908) as Tapirus †pandanicus (Dubois, 1908), but this name has been synonymized with $T$. indicus (Hooijer 1947; Storm 2001). The associated fauna of large mammals comprised a rich mix of extinct genera and archaic forms of extant genera (Table 1.) In all Javan sites, Malayan tapir remains were disproportionately scarce by comparison with other large mammal species, being represented by only 6 teeth from Kedung Brubus, Kedung Lumbu and Kebun Duren in the Kendeng hills (Hooijer 1947; Storm 2001).

In Peninsular Malaysia, cave washings in Perak yielding Elephas †namadicus Falconer \& Cautley, 1846, Rhinoceros, Hexaprotodon and $\dagger$ Duboisia (Andrews 1905; Hooijer 1962a) have confirmed that a Sino-Malayan fauna, presumed to be of Middle Pleistocene age, extended to the continental part of the Sundaic subregion. Dated finds of mid-Middle Pleistocene age ( $600 \mathrm{ka})$ in the Lenggong Valley, Perak, include Malayan tapir with an assemblage of other extant large mammal genera with Middle Pleistocene origins that have, like Malayan tapir, survived into modern times (Yasamin et al. 2010).

\section{Late Pleistocene (126-10 ka)}

The ape $\uparrow$ Gigantopithecus was absent from Late Pleistocene SEA, its last dated occurrence being 380$310 \mathrm{ka}$ (Rink et al. 2008). In the Indochinese subregion other archaic Middle Pleistocene megafauna genera and species did survive for many millennia through the LGP. In southern China, for example, giant tapir and Malayan tapir were both present during the LGP, with orangutan, 2 hyenas $H$. $\dagger$ brevirostris and Crocuta crocuta (Erxleben, 1777), $\dagger$ S. orientalis, E. †namadicus and $R$. $\dagger$ sinensis. There is evidence that hyena Crocuta, $\dagger$ Stegodon and giant tapir even persisted into the Holocene (Louys et al. 2007). If correctly dated, the Keo Leng site in Vietnam shows that giant tapir was certainly present up to the LGM, with orangutan and giant panda and a transitional fauna in which $\dagger S$. orientalis, $E$. $\dagger$ namadicus, $R$. $\dagger$ sinensis and Sus †lydekkeri Zdansky, 1923 occurred alongside an essentially modern assemblage of smaller primates, Indian rhinoceros, Eurasian wild pig, deer, wild buffalo and serow (Table 1; Tougard 1998; Louys et al. 2007).

In the Sundaic subregion there was greater variability, both geographical and temporal, during the Late Pleistocene. In Java, at Punung near the south coast, a combination of caves and open breccias of Last Interglacial age, dated at $128 \pm 15$ to $118 \pm 3 \mathrm{ka}$ (Westaway et al. 2007), yielded a fully modern fauna that included Malayan tapir with rainforest-dependent species, orangutan, siamang, gibbon and sun bear (also a rainforest indicator) as well as macaque and langur, Asian elephant, Javan rhinoceros, pigs indentified as Eurasian wild pig, bearded pig and Javan warty pig Sus verrucosus Boie, 1832, muntjac and other deer, banteng Bos javanicus D'Alton, 1923, buffalo and serow. The mammal community at Song Terus, dated $120-80 \mathrm{ka}$, has also been judged to represent a modern tropical rainforest fauna (Anysori 2010), denoted by the presence of moonrat Echinosorex sp., siamang, Javan warty pig and Indian muntjac Muntiacus muntjak (Zimmermann, 1780). In the Late Pleistocene sites at Punung and Song Terus, the absence of archaic large mammals recorded at sites such as Ci Saat, Trinil and Kedung Brubus suggests an extinction event in Java associated with the environmental upheavals at the beginning of the penultimate interglacial period around $120 \mathrm{ka}$, when open woodland and grassland landscapes were replaced by the dense tropical rainforests (van den Bergh et al. 2001). †S. trigonocephalus, Elephas †hysudrindicus Dubois, 1908, Hexaprotodon $\dagger$ sivalensis Falconer and Cautley, 1836, Axis $\dagger$ lydekkeri Martin, 1886, Bubalis †palaeokerabau Dubois, 1908 and $\dagger D$. santeng all disappeared along with other archaic bovids and suids. Large mammals that appear to have had the ecological flexibility to endure through this transition include tiger, Javan rhinoceros, Malayan tapir, with modern forms of pigs and other cervids and bovids.

Tropical rainforest environments then seem to have persisted in Java until c. $80 \mathrm{ka}$ when there was once again a climatic reversal towards drier and more open 
conditions (van der Kaars \& Dam 1995). This transition is recorded in the fauna of the partially collapsed cave Song Gupuh, where over $16 \mathrm{~m}$ of deposits yielded a rich sequence dated by mixed methods from about $70 \mathrm{ka}$ to $1 \mathrm{ka}$, i.e. mid-LGP to first millennium AD. Malayan tapir was present, but orangutan and other obligatory rainforest primates of the Punung assemblage were lacking. The remaining species were entirely modern: long-tailed macaque Macaca fascicularis (Raffles, 1821), sun bear, Asian elephant, Javan rhinoceros, Eurasian wild pig and Sus indet., deer Cervus sp., muntjac and bovines Bos sp. and Bubalus sp. (Table 1; Morwood et al. 2008).

The controversial Ngandong site, Central Java, was dated at 53-27 ka, i.e. mid to late LGP, by Swisher et al. (1996). The large mammals included Malayan tapir, with genera and species of Middle Pleistocene affinity such as H. $\dagger$ brevirostris, Rhinoceros unicornis $\uparrow$ kendengindicus Dubois, 1908, bovid †Epileptobos groeneveldtii Dubois, 1908 and pig Sus †macrognathus Dubois 1908 (Table 1; Storm 2001; van den Bergh et al. 2001). On biostratigraphic grounds, de Vos and Sondaar (1994) considered that the Ngandong fauna was older than Punung. Although Curtis et al. (2002) reiterated confidence in the terminal Pleistocene date, an alternative redating of the Ngandong stratigraphy suggested that the site and the fossils it contained were no younger than Oxygen Isotope Stage 5 (Westaway et al. 2002, 2007).

At the inception of the Holocene epoch in Java, Malayan tapir was present at Wajak, ${ }^{14} \mathrm{C}$ dated at $10560 \pm 65$ BP. The associated mammals consisted of modern species but included only a langur among primates, with tiger, Javan rhinoceros, Eurasian wild pig, banteng, modern buffalo and Javan deer Rusa timorensis (Blainville, 1822) suggesting the persistence, at least in this part of Java, of relatively open, lightly wooded environments (Table 1; Storm 2001).

In Sumatra, collections made by Dubois in 1888 1890 in limestone caves near Padang have an estimated age of 80-60 ka (de Vos 1983; Drawhorn 1995). Tapir remains (exclusively teeth) were described as a large chrono-subspecies of Malayan tapir Tapirus indicus †intermedius Hooijer, 1948. The distinction was challenged by Badoux (1959), but the subspecies name has been used by others to identify large-toothed Middle or Late Pleistocene Malayan tapirs elsewhere (see Table 1). The orangutan of these caves was also described as an extinct chrono-subspecies Pongo (abelii) †palaeosumatrensis Hooijer, 1948, averaging larger in dental measurements than modern comparatives. Other remains were extant forms (Table 1; Hooijer 1948; de Vos 1983).
In Peninsular Malaysia, Malayan tapir has been identified in Late Pleistocene sites at Batu caves, Selangor, associated with an assemblage of extant mammal genera or species of Middle Pleistocene origin, including orangutan, long-tailed macaque, canid, sun bear, tiger, rhinoceros sp. indet., Eurasian wild pig and bearded pig, sambar, muntjac and serow (Yasamin et al. 2010, 2013).

In northwestern and northern Borneo, Late Pleistocene sites overlapping chronologically with Song Gupuh and Wajak show the presence of a richer assemblage of large mammals of forms associated with tropical rainforest, with Malayan tapir also present. At the West mouth, Niah caves, Sarawak, securely dated from about 50 ka through the Holocene (Barker et al. 2007), among a very large collection of mammalian remains, only 1 extinct taxon was represented: giant pangolin Manis cf. †palaeojavanica Dubois, 1907, a single individual in a context datable to $45 \mathrm{ka}$ (Piper et al. 2007a). The remainder included a diverse sample of modern mammal fauna with the addition of tiger (Piper et al. 2007b), Javan rhinoceros (Cranbrook \& Piper 2007) and Malayan tapir (Cranbrook \& Piper 2009), 3 species no longer extant in Borneo. Others included orangutan Pongo pygmaeus (Linnaeus, 1760), extending throughout the profile, gibbon Hylobates muelleri Martin, 1841, long-tailed and pig-tail macaques, maroon ?langur Presbytis ?rubicunda (Müller, 1838) and silvered langur Trachypithecus cristatus (Raffles, 1821), sun bear, Sumatran rhinoceros, bearded pig, muntjac, sambar Rusa unicolor (Kerr, 1792) and banteng (Table 1; Hooijer 1961, 1962b,c; Cranbrook 2010).

Although occurring widely in terminal Pleistocene and Holocene sites of northwest Borneo, Malayan tapir was again represented in very small numbers. The sum of items identified from all sites amounts to 6 teeth and 19 foot bones (Tables 2 and 3). From 2 major mouths of Niah caves (West mouth and Gan Kira combined) P. J. Piper and associates (Piper \& Rabett 2013) assessed a total of 10683 identifiable whole or fragmentary bones and teeth of large or medium-sized mammals, of which only 19 items $(0.18 \%)$ represented the Malayan tapir.

Superficial finds in an archeological context indicate a recent date. Juvenile canines found at $0-6$ inches $(0-15 \mathrm{~cm})$ depth at the Gan Kira mouth of Niah caves and also on the surface of the cave soil in Sireh cave (Table 2; Cranbrook 2013a) were potentially deposited not long ago. Four foot-bones of tapir in the A. H. Everett Collection in the Paleontology Department of the Natural History Museum, London (reg. nos. M83323- 
4, M83782-3) were recovered from Everett's Excavation B, Cave V, Jambusan, Sarawak (Table 3; Cranbrook 2004; Cranbrook \& Piper 2009; Cranbrook 2013b). In a subsequent excavation of an adjoining cave, No. XIII, known as Tupak, by Gani et al. (2009), charcoal samples from Trench A, $30-40 \mathrm{~cm}$, gave ${ }^{14} \mathrm{C}$ ages of CalBP 470-270, i.e. AD 1480-1680 and other samples were more recent. Everett's excavations in Cave V extend- ed deeper, to $90 \mathrm{~cm}$. The depth at which the Malayan tapir foot-bones were found was not recorded but, by inference, it is possible that they too dated from no more than a few centuries ago.

Although situated on the northeastern fringes of the Sunda Shelf and intermittently connected to Borneo during the Middle Pleistocene (Heaney 1985, 1986), Palawan is the only large island in the Sundaic subregion

Table 2 Teeth of Malayan tapir from Sarawak, Borneo, recorded by the trench and depth from which they were recovered in each of their respective sites and the approximate age of the bones (modified from Cranbrook \& Piper 2009). A left lower mandibular canine in Y/D1 24-30 ins (No. 5) and a 1st left maxillary molar in Y/A1 0-6 ins (No. 6) from the Gan Kira entrance to the Niah caves have been added to the list (Fig. 2a,b). Note: the 2 deciduous upper canines from L3 15-20 cm and the lower deciduous premolar (exact provenance unknown) from Madai Cave, Sabah, illustrated in Cranbrook and Piper (2009), were misidentified as tapir and have consequently been omitted from this list

\begin{tabular}{llllll}
\hline$\#$ & Cave site & Element & Trench & Depth (inches) & Period \\
\hline 1 & Niah, West mouth $^{1}$ & R maxillary canine & E/G 1 & $30-36$ & $?$ \\
2 & Niah, West mouth $^{1}$ & L maxillary canine (split)* & E/G 1 & $42-48$ & $?$ \\
3 & Sireh Cave $^{2}$ & R mandibular canine (juvenile) & Surface & 0 & Sub-recent \\
4 & Niah, West mouth $^{2}$ & L mandibular canine (adult) & NCP 01 & $(2044)$ & $?$ \\
5 & Niah, Gan Kira & L mandibular canine (sub-adult) & Y/D1 & $24-30$ & Early Holocene? \\
6 & Niah, Gan Kira & L maxillary M1 (sub-adult) & Y/A1 & $0-6$ & Sub-recent? \\
\hline
\end{tabular}

*Damaged or fragmentary specimen; ${ }^{1}$ Medway (1961); ${ }^{2}$ Cranbrook and Piper (2009).

Table 3 Post cranial skeletal elements of Malayan tapir from cave sites in Sarawak, Borneo, recorded by the trench and depth from which they were recovered in each of their respective sites and the approximate age of the bones (modified from Cranbrook \& Piper 2009)

\begin{tabular}{|c|c|c|c|c|c|}
\hline \# & Cave site & Item & Trench or BM reg. no & Depth (inches) & Period \\
\hline 1 & Niah, West mouth ${ }^{2}$ & L magnum, lateral portion * & HQ 5 & $84-87$ & Late Pleistocene \\
\hline 2 & Niah, West mouth ${ }^{1}$ & Metatarsal III R (proximal)* & $\mathrm{W} / \mathrm{E} 1$ & $24-36$ & Early Holocene \\
\hline 3 & Niah, West mouth ${ }^{1}$ & Metapodial III (distal)* & $\mathrm{W} / \mathrm{E} 1$ & $24-36$ & Early Holocene \\
\hline 4 & Niah, West mouth ${ }^{1}$ & Metapodial III (distal)* & $\mathrm{X} / \mathrm{W} 1$ & $48-60$ & Terminal Pleistocene \\
\hline 5 & Sireh Cave ${ }^{1}$ & Metatarsal IV R (proximal)* & $\mathrm{B} / 10$ & $24-30$ & Mid/Late Holocene \\
\hline 6 & Niah, West mouth ${ }^{3}$ & Metacarpal II or IV (proximal)* & $\mathrm{X} / 2$ & $24-48$ & Mid/Late Holocene \\
\hline 7 & Niah, West mouth ${ }^{1}$ & Cf. metatarsal II R (distal)* & $\mathrm{Y} / 1(\mathrm{~A})$ & $54-60$ & Terminal Pleistocene \\
\hline 8 & Niah, West mouth ${ }^{1}$ & Lateral metapodial (distal)* & $\mathrm{X} / 2$ & $24-36$ & Mid/Late Holocene \\
\hline 9 & Niah, West mouth ${ }^{3}$ & Cf. metatarsal II L (proximal)* & $\mathrm{E} / \mathrm{W} 5$ & $33-36$ & Early Holocene \\
\hline 10 & Niah, West mouth ${ }^{1}$ & Lateral basal phalanx & $\mathrm{E} / \mathrm{C} 1$ & $24-48$ & Early Holocene? \\
\hline 11 & Niah, West mouth ${ }^{1}$ & Lateral basal phalanx & $\mathrm{E} / \mathrm{B} 2$ & $48-60$ & Terminal Pleistocene? \\
\hline 12 & Cave V, Jambusan ${ }^{3}$ & Lateral basal phalanx, cf. II (pes) & M83324 & Exc. B & Late Holocene/recent \\
\hline 13 & Niah, West mouth ${ }^{3}$ & Basal phalanx II & $\mathrm{X} / \mathrm{V} 1$ & $60-72$ & Late Pleistocene \\
\hline 14 & Niah, West mouth ${ }^{2}$ & Subterminal phalanx I or IV (manus) & HQ9 (B) & $78-81$ & Late Pleistocene \\
\hline 15 & Cave V, Jambusan ${ }^{3}$ & Subterminal phalanx II (manus) $\mathrm{R}$ & M83323 & Exc. B & Late Holocene/recent \\
\hline 16 & Niah, Gan Kira ${ }^{1}$ & Lateral subterminal phalanx & Y/A 21 & $30-36$ & Early Holocene? \\
\hline 17 & Cave V, Jambusan ${ }^{3}$ & Terminal (ungual) phalanx digit III* & M83782 & Exc. B & Late Holocene/recent \\
\hline 18 & Niah, West mouth ${ }^{1}$ & Ungual phalanx digit III* & $\mathrm{E} / \mathrm{C} 1$ & $0-24$ & Late Holocene \\
\hline 19 & Cave V, Jambusan $^{3}$ & Proximal metapodial (indet)* & M83783 & Exc. B & Late Holocene/recent \\
\hline
\end{tabular}

*Damaged or fragmentary specimen; ${ }^{1}$ Medway $(1961) ;{ }^{2}$ Hooijer (1962b); ${ }^{3}$ Cranbrook (2012b); and this paper. 
where tapirs have yet to be recorded. Currently the oldest well-studied vertebrate assemblage, from Ille Cave in the north of the island, dates from c. 14 ka through the terminal Pleistocene and Holocene (Lewis et al. 2008; Ochoa 2008; Piper et al. 2008, 2011). Primarily hunted by humans, but also likely including a component of a natural death assemblage, 27 different extant and locally extinct mammal taxa were identified, including Philippine long-tailed macaque Macaca fascicularis philippinensis Geoffroy, 1843, Palawan pangolin Manis culionensis Elera, 1915, arrow-tailed flying squirrel $\mathrm{Hy}$ lopetes nigripes Thomas, 1893, Palawan spiny rat Maxomys panglima Robinson, 1921, Palawan porcupine Hystrix pumila Günther, 1879 and Palawan stink badger Mydaus marchei Huet, 1887 (Piper \& Ochoa 2007; Ochoa 2008; Piper et al. 2008, 2011). Most significantly, the Ille Cave bone assemblages produced the first records of 2 species of deer Rusa sp. and Calamian hog deer Axis calamianensis Heude, 1888, possibly dhole and the former presence of tiger.

Reconstructions of Palawan paleogeography and past environment suggests that the island then covered almost $80000 \mathrm{~km}^{2}(>80 \%$ larger than its current Holocene landmass) and was joined with Busuanga and $\mathrm{Cu}-$ lion to the north and Balabac to the south (Piper et al. 2011). The climate was cooler and drier than at present and the vegetation probably consisted of open woodland and savanna rather than the tropical rainforests that characterize the island today (Bird et al. 2007; Wurster et al. 2010). The Pleistocene landscapes of Palawan with their more open environments and large deer populations must have been sufficient to support tiger and dhole populations. There is, however, no evidence that Malayan tapir reached Palawan, possibly testifying to a limited capacity to cross maritime barriers that did not prevent the invasion of other large mammal species.

\section{DISCUSSION}

\section{Local radiation and size changes within Quaternary SEA}

Of 2 clades of tapirs of Early and early Middle Pleistocene SEA, one lineage $T$. $†$ sanyuanensis $>T$. $\dagger$ sinensis > giant tapir T. (M.) †augustus trended towards larger size. Around the Early-Middle Pleistocene transition, $T$. † sinensis occurred on both sides of the eastern Palearctic/Indomalayan faunistic boundary and at some sites both this species and its apparent descendant giant tapir were sympatric with forms of Malayan tapir, represent- ing the smaller, strictly SEA clade. Comparable Quaternary sympatries included, among Primates, the large ape $\dagger$ Gigantopithecus found with smaller orangutans Pongo. If the taxonomy of Schwartz et al. (1995) is valid, radiation of hominoids in Middle Pleistocene north Vietnam produced an additional genus $\dagger$ Langsonia, a large orangutan $P$. †hooijeri and a diversity of distinctive local clades of Pongo described as chrono-subspecies, all larger than ancestral P. pygmaeus. Among Carnivora, a large extinct dog $\dagger$ Megacyon co-occurred with precursors of the dhole. The Neogene bear Ursus †minimus Linnaeus, 1758 was ancestral both to Asian black bear and the smaller sun bear. Archaic forms of both bears occurred in Middle Pleistocene SEA sites (Table 1). Asian black bear also ranged into Europe in the Pleistocene. Competition with the largely herbivorous cave bears Ursus †speleus Rosenmüller, 1794 may have been a factor in its extirpation from its west Eurasian range (McLellan \& Reiner 1994). The range of Asian black bear extended to Peninsular Malaysia (Yasamin et al. 2013) but did not reach Sumatra, Java or Borneo.

Only the sun bear has survived to the present in the Sundaic subregion. Comparison of faunal lists (Table 1) shows that, similarly, the larger member of the pair has become globally extinct or locally absent from SEA, suggesting selective pressures favouring smaller size. By the Holocene, if not before, giant tapir was extinct while Malayan tapir survives until today in SEA, albeit in a restricted range, low numbers and threatened circumstances. Among such long-enduring mammal species, ancient forms also tend to be larger than modern representatives. In some instances, size differences have been recognised by description of the archaic form as chrono-subspecies including Malayan tapir $T$. indicus $\uparrow$ intermedius and orangutan P. (abelii) $\dagger$ palaeosumatrensis of Late Pleistocene Sumatra (Hooijer 1947, 1948).

\section{The paleoenvironment}

Perceptions of paleohabitats can be deduced from faunistic evidence, by reference to the known habits of modern mammal genera and species (Louys et al. 2007). The earliest Quaternary mammal megafauna of SEA included large proboscideans with comparatively low-crowned molars implying a browsing habit, rhinoceroses (again browsers), hippopotamus that must have required large water-bodies and riparian grazing, with pigs, deer and cattle of genera represented in modern tropical wooded habitats. A mix of large carnivores re- 
flected diversity in prey. Horses and gazelle, which require extensive grazing lands, penetrated only to peripheral sites in southern China and central Burma (Table 1). Here, the indicated paleoenvironment was subtropical savannah or semi-open woodland, probably with areas of swamp vegetation surrounding large water bodies and abundant glades or grassland gaps.

Evidence of Middle Pleistocene forested paleoenvironments in SEA is derived from a variety of sources, including palynology and paleophytogeography (Wong 2011). Zoological indications include the presence of giant panda which (in its present ecology) is dependent on sub-temperate bamboos. The range of giant panda did not extend into the Sundaic subregion, presumably marking the distribution of prevailing environments supporting these bamboos. A second Middle Pleistocene indicator species in SEA was the ape $\dagger$ Gigantopithecus, which was distributed over a similar range. The association of this large ape (and $\uparrow$ Langsonia) with a third Middle Pleistocene hominoid genus, orangutans Pongo spp., suggests that their ecological requirements overlapped. Yet $\dagger$ Gigantopithecus disappeared from the paleontological record after about $300 \mathrm{ka}$ while Pongo continued to expand and diversify throughout SEA. The 2 living orangutans, Pongo abelii Lesson, 1827 and P. pygmae$u s$, are the most arboreal of the great apes. Even though their ecological versatility and adaptability are demonstrated by the survival, in present times, of individuals or small breeding populations in degraded forests (Payne \& Prudente 2008; Wich et al. 2008), in their respective ranges both species are none the less good indicators of forested environments of some form.

Bacon et al. (2008) noted the strong similarity between the composition of the completely modern Late Pleistocene fauna at Duoi U'Oi Cave in northern Vietnam (c. $66 \pm 3 \mathrm{ka})$ and those of the Sundaic subregion and, specifically, the Padang sites in Sumatra which included orangutan, siamang, sun bear, elephant, Eurasian wild boar and bearded pig (see also Long et al. 1996). They concluded that similar ecological conditions, consisting of tropical forests, are likely to have existed across much of mainland and island SEA. However, analysis of the distributions of extant Thai mammals emphasizes the significance of the transition zone around $10^{\circ} \mathrm{N}$ between the present distinctive Indochinese and Sundaic subregional faunas (Lekagul \& McNeely 1977). That a barrier to genetic exchange has existed for a long time is confirmed, for instance, by molecular evidence of separate evolutionary histories of Indochinese and Sundaic gibbons, Hylobates spp. (Thinh et al. 2010). At Pleistocene high sea levels (i.e. interglacials) the narrow Thai-Malay peninsula could have impeded the migration of large mammals. However, mid or low sea levels prevailed for most of the Quaternary, providing a broader land corridor between the Indochinese and Sundaic subregions of SEA (Cannon et al. 2009). The existence of an Early Pleistocene connection is confirmed by Sundaic megafauna assemblages in Java that showed affinity with Siwalik and contemporary Indochinese subregional faunas, including browsing proboscideans, hippopotamus, deer, cattle and an antelope, indicative of an open woodland or savannah habitat, with large surface water-bodies. Although there is no evidence that the Early Pleistocene immigration included Malayan tapir, at its first appearance in Middle Pleistocene Java (at Kedung Brubus, 800-700 ka) the species was associated, albeit sparsely, with a faunal assemblage indicating comparable habitat.

At low sea levels, huge northward draining rivers may have impeded the movement of some terrestrial mammals across the exposed bed of the South China Sea (Verstappen 1975), but environmental conditions appear to have provided a more decisive barrier. Expansion and retreat of zonal and altitudinal forest types must have followed the glacial cycles. Genetic divergence between the 2 living species of Pongo points to separation since around $400 \mathrm{ka}$ (Locke et al. 2011) thereby setting a Middle Pleistocene date after which no further gene exchange occurred between antecedents of $P$. pygmaeus in Borneo and P. abelii in Sumatra, as a consequence of the severance of connected habitat suitable for orangutans. From the collective distributions of recent primates, Brandon-Jones (1998) inferred that SEA rainforest was subsequently fragmented by glacial drought around $190 \mathrm{ka}$ and again at about $80 \mathrm{ka}$, leaving only refugial remnants in Sumatra and Borneo.

That paleoenvironmental factors prevented genetic exchange between eastern and western Sundaic forest refugia is supported by evidence of a corridor of savannah habitat, from which obligate forest-dwelling mammals would have been excluded, extending from Java to the Thai-Malay peninsula at the LGM and, by inference, also during previous Pleistocene glaciations (Bird et al. 2005; Wurster et al. 2010). Of 4 scenarios for terminal Pleistocene environments modelled by Cannon et al. (2009), 2 simulate the separation of eastern (Bornean) and western (central Sumatran) lowland evergreen rainforest blocks, while 2 simulate a narrow corridor from central Sumatra, Bangka and Belitung across the Karimata Strait to western Borneo. If such a corridor existed, 
it might have facilitated the migration of some forestadapted mammals, but evidently did not permit genetic exchange between the 2 Pongo species.

Although these climatic events affected the later Quaternary history of forest-dwelling mammals of the Sundaic subregion, Malayan tapir was probably protected by its ecological versatility. During the last interglacial, Malayan tapir was present at Punung, Java, associated with orangutan, gibbon and other large mammals ecologically confined to forest habitat. During the LGP, on the evidence of the faunas of Song Gupuh and Wajak (van den Bergh et al. 2009; Storm et al. 2005; Table 1), by $70 \mathrm{ka}$ these forest indicator species were no longer present, while Malayan tapir remained among a surviving large mammal fauna denoting open woodland habitat. If the chronological date of Ngandong is correct (rather than biostratigraphical indications), conditions in mid-Late Pleistocene in Java also permitted the retention (or return) of a more archaic megafauna, indicative of well-watered, savannah-like habitat where, again, Malayan tapir was present.

Within Borneo, there is additional evidence of local Middle Pleistocene constriction of forest habitat. Among Borneo orangutans, phylogenetic reconstruction based on mtDNA sequences from 211 wild individuals from all parts of the island have determined time to the most recent common ancestor (TMRCA) at 322-71 ka (Arora et al. 2010). It appears that the population has passed through a bottleneck, expanding since late Middle or Late Pleistocene from a restricted area, i.e. a forest refugium. Among gibbons, smaller but more strictly arboreal and forest-adapted primates, a TMRCA of $1.78 \mathrm{Ma}$ for Borneo gibbon indicates a long period of differentiation within the island, consistent with the confinement of the population within Middle to Late Pleistocene forest refugia (Thinh et al. 2010). Northwest Borneo has been identified as the location of such a refugium during the Late Pleistocene, supported by the confirmed presence at Niah caves of arboreal primates including orangutan, gibbon, macaques Macaca and langurs Presbytis and Trachypithecus, with sun bear and Malayan tapir in contexts dated from c. $50 \mathrm{ka}$, through the terminal Pleistocene and Holocene (Table 1).

The mix of rat species at Niah in the Late Pleistocene provides further insight into the prevailing environment. The murine species identified include long-tailed giant rat Leopoldamys sabanus (Jentink, 1879), a good climber and normal denizen of closed tall forest, with 2 species that in their present ecology frequent forest fringe and disturbed or secondary woodland vegetation: Mül- ler's rat Sundamys muelleri (Jentink, 1880) and field rat Rattus sp. cf. tiomanicus (Miller, 1900). While supporting other evidence of a forest refugium in northwestern Borneo, the presence of Rattus sp., in particular, indicates that the physiognomy of the vegetation more likely resembled that of present heath forests, secondary forests and other disturbed forest habitats, rather than the tall, closed rainforest that is the normal climax vegetation today at lowland elevations (Cranbrook \& Piper 2008).

\section{Tapirs and Quaternary megafauna extinctions in SEA}

Although technology has provided some chronometric dates to supplement biostratigraphy, certainty limits are wide and it is not possible to correlate faunal assemblages with recognized Pleistocene glacial cycles prior to the last interglacial. It is clear, however, that in the Early Pleistocene, a combination of climatic and geographical opportunities permitted some members of a late Neogene mammal fauna of central and south Asia with compatible ecology to expand into SEA. Faunal lists (Table 1) show that, subsequently, rather than one or more major episodes of extinction, throughout the Quaternary of SEA there has been progressive replacement of members of this archaic large mammal fauna with modern genera and species (cf. Corlett 2010).

For example, Bacon et al. $(2008,2011)$ proposed a biochronological sequence for well-documented faunas of the Indochinese subregion, from the cave sites of Yenchingkuo (Middle Pleistocene, China), Thum Wiman Nakin (late Middle Pleistocene, Thailand), Tham Hang South (late Middle Pleistocene-Late Pleistocene, northern Laos), Phnom Loang (Middle Pleistocene, Cambodia) and Duoi U'Oi, Ma U'Oi and Lang Trang (Late Pleistocene, northern Vietnam). They proposed that the earliest faunal community in the middle-late Middle Pleistocene consisted of extinct species such as $\dagger S$. orientalis, E. †namadicus, H. †brevirostris (Yenchingkuo only) and giant tapir, associated with modern species/chrono-subspecies showing few advanced evolutionary stages like Arctonyx collaris cf. †rostrastus Matthew \& Granger, 1923, T. indicus cf. $\dagger$ intermedius, Ursus thibetanus $\mathrm{cf}$ † $\uparrow$ kokeni Matthew \& Granger, 1923 and Cuon alpinus cf. †antiquus (Matthew \& Granger, 1923). The early Late Pleistocene assemblage from Lang Trang (100-80 ka) is distinguished from preceding and succeeding communities by its relative modernity, including the Asiatic black bear, giant panda and Sumatran rhinoceros, but with some archaic 
elements such as $\uparrow S$. orientalis and probable records of E. † namadicus and the extinct giant tapir and T. indicus †intermedius. The Late Pleistocene sites of Duoi U'Oi $(66 \pm 3 \mathrm{ka})$ and Ma U'Oi (47 $\pm 4 \mathrm{ka})$ contain a fully modern faunal community including pigs, dhole, Asiatic black bear, Sumatran and Javan rhinoceros and Malayan tapir.

In the Middle Pleistocene, as some members of the early megafauna became extinct and others evolved into descendent forms, tapirs, evidently at home in an open wooded paleoenvironment, diversified and spread through the Indochinese region. The generic tolerance of varied habitat is shown by the appearance of giant tapir at sites dated between $475 \mathrm{ka}$ and $20 \mathrm{ka}$ in southern China and Vietnam. Giant tapir and Malayan tapir were sympatric at a site in southern China and at Tam Hang S., Laos. However, ancestral Malayan tapirs spread further into the Sundaic subregion, reaching Java from at least $800-700 \mathrm{ka}$ in association with other large ungulates whose presence indicates an open wooded and well-watered landscape. The very low representation of tapirs compared with other large ungulates suggests that they were rare, probably occupying marginal habitats in the prevailing environment.

Cyclic post-glacial restoration of warm climate and high rainfall across the region would have prompted the periodic expansion of closed forest from refugia. Such an ecological change, operating at a Middle Pleistocene interglacial cycle, could therefore account for the disappearances of early savannah-adapted megafauna mammals. In the Sundaic subregion, periodic high sea levels at interglacials caused fragmentation of exposed land area, thereby intensifying evolutionary processes among isolated populations. In the Late Pleistocene, these same cyclic changes from cool to warm climate continued to favour smaller against larger members of related taxa and, when there was no interspecific competition, progressive reduction in size. The process is reflected in the disappearance of the giant tapir and survival of Malayan tapir.

Large mammals themselves impact on their environment. In suitable climates and soil conditions, mammals such as proboscideans or rhinoceroses, by trampling and browsing, can maintain shrubby habitat and foster ruderal softwood species characteristic of disturbed forests. Such conditions match the feeding requirements of Malayan tapirs. The zooarcheological evidence, including identification of field rats at deep levels in Niah caves, Sarawak, supports the conclusion that the vegetation cover of lowland northwest Borneo during the ter- minal Late Pleistocene had the character of disturbed forests, rather than the tall 'cathedrals' popularly visualized as pristine tropical evergreen rain forest. Without humans, the large browsing mammals themselves could have maintained sub-climax forest vegetation, while the grazing community of cattle, buffalo and others, could have kept open unforested gaps and glades.

In the Sundaic subregion at the LGM, as at previous glacial maxima, a comparatively cool, arid and more seasonal climate would have reduced the extent of tall, closed tropical rainforest, which retreated to constrained refugia. The subsequent return to interglacial conditions of warmth and high, non-seasonal rainfall favored the resurgence of rainforest vegetation. Once the regrowth of tall trees outstripped the physical capacity of the large mammals to maintain the habitat structure necessary for their sustenance, megafuana species including Malayan tapir would have suffered from diminished resources. In Borneo, in addition to botanical evidence of floristic sequences in the terminal Pleistocene (Bird et al. 2005), dramatic changes in the representation of cavernicolous bats at Niah and Jambusan, Sarawak, have been interpreted as consequences of environmental change (Cranbrook 2010). Although probably skewed by the preponderance of hunted quarry among mammal remains (see below), the low representation of remains of Malayan tapir at Niah again indicates that, in the terminal Pleistocene and early Holocene environments, the species continued to be rare. It is likely that the ecological versatility of Malayan tapir permitted it to survive through successive climatic transitions, occupying a range of habitats that appear to have varied from dense tropical rainforest to open woodland.

The presence in Borneo and Palawan of dhole and tiger, characteristic mammals of Middle and Late Pleistocene SEA, demonstrates that in the past both species had a wider Sundaic distribution than historically recorded. However, there is as yet no evidence that Malayan tapirs crossed the intervening geographic or ecological barrier.

\section{Human impact}

The Quaternary megafauna extinctions of Late Pleistocene Australia and North America have been linked with the arrival of modern humans in these continents (Flannery 1994, 2001). The longer existence of Homo spp. in SEA makes it more difficult to assess the relative impact of humans on the regional megafauna. The general conclusion of SEA regional reviews is that human interventions, including habitat modification and hunt- 
ing, are likely to have intensified the effects of climatic and environmental change, to the detriment of megafauna mammals in particular (Louys et al. 2007; Corlett 2010).

In Java, a forest-adapted mammal fauna flourished at Punung during the last interglacial but, at nearby Song Gupuh, during the LGP from $70 \mathrm{ka}$ indicator species of closed forest had been lost, as progressive cooling and desiccation took hold. The disappearance of those mammals most dependent on closed forest was attributed to ecological factors by van den Berg et al. (2001) and Storm et al. (2005), although the later identification of a possible modern human tooth has raised a question mark (Morwood et al. 2008). In Borneo, at Niah caves, modern humans were associated throughout the zooarcheological sequence, which has been dated from about 50 ka to near recent (Barker et al. 2007).

It has been argued that the local extinction of several large mammals on Palawan was, at least in part, due to human hunting pressure. From the Late Pleistocene, sea levels rose to a height estimated to have been between $0.3-1.5 \mathrm{~m}$ higher than at present. At the same time, the environment of the island reverted from open woodland and grassland to the now dominant evergreen tropical rainforests. The animal bone assemblage of Ille Cave, derived primarily from human hunting, chronicles the disappearance of the tiger, deer and dhole, probably as the combined result of changing environment, habitat loss and human predation-the last almost certainly intensified for deer. As deer numbers diminished, the human populations inhabiting the cave switched their main prey resource to the more forest adapted endemic wild pig Sus ahoenobarbus Huet, 1888 (Ochoa 2008; Piper et al. 2011; Ochoa \& Piper 2013).

Did hunting by humans similarly exacerbate the environmental changes faced by Malayan tapirs throughout their Quaternary range? The species has a potentially long life-span, with a record (in captivity) of 31 years. Reflecting this long life expectation, recruitment is slow: after 13 months gestation normally one young is born, which then accompanies its dam for several years (biodata from Medway 1983). Johnson (2006) has modelled different levels of off-take applied to any large mammal with these characteristics and shown that a small increase in the mortality of juveniles can hold recruitment rate below levels needed to replace natural mortality of breeding adults. It is notable that in all sites in Borneo, the majority of dental remains of Malayan tapir represent juveniles (Table 2; Cranbrook \& Piper 2009). At Niah, pigs were the principal ground quarry, accounting for $90-95 \%$ of all ungulate bones recovered from the excavations; by comparison, remains of tapir were trivial in number (Piper \& Rabett 2009, 2013). In a post glacial environment which had become suboptimal for the survival of Malayan tapir, hunting strategies that were targeted at pigs, but unintentionally or deliberately also trapped juvenile tapirs, could tip the balance and precipitate extinction. This impact would have been intensified when Iron Age weaponry arrived and, ultimately, shotguns were introduced.

\section{FROM PALEONTOLOGY TO POLICY: A PROPOSAL FOR THE REINTRODUCTION OF THE MALAY TAPIR TO BORNEO}

The Malayan tapir has been shown to be the last remaining Old World species within the ancient family Tapiridae, with a known history that extends back some 1.5 Myr in SEA. Although primitive in form among Perissodactyla, this member of the ancient Quaternary megafuana has proved remarkably adaptable and durable, throughout its long history co-existing with many different mammalian communities and apparently thriving in many different climatic and ecological regimes. As shown above, there is zooarcheological evidence in Borneo that Malayan tapir has been a member of faunal communities on the island from at least $\sim 50 \mathrm{ka}$ to within the last few hundred years (see also Cranbrook \& Piper 2009). Although there are no authenticated specimens in Museum collections, it has been claimed that Pierre Diard, who toured what is now West Kalimantan in 1826, obtained a specimen in the interior of Pontianak (Smythies 1960). Eye-witness reports of Malayan tapirs in Sarawak, Brunei and Sabah, as late as 1931, have been summarized elsewhere (Piper \& Cranbrook 2007; Cranbrook \& Piper 2009). It is probable that Malayan tapirs, although extremely rare, were still fairly widespread across northwest and northern Borneo up to that time. Medway (1977) conjectured that during the global economic depression of the 1930s, when the remaining rhinoceroses in Borneo were almost exterminated by trophy hunters, the last Malayan tapirs, not much smaller in size and with similar habits, may have suffered with them and finally been exterminated.

Although shy and secretive, Malayan tapirs tolerate contact with people and disturbance by human activity in rural areas. In Peninsular Malaysia, unmolested ta- 
pirs have survived for long periods in secondary habitat close to settlements (Mohd Khan 1997). Trial trapping and immobilisation of wild animals has been successful (Williams 1978a,b). Malayan tapirs in zoos take almost any vegetable food and some captive pairs have proved fecund, e.g. 10 births at San Diego were reported by Ryder (in Medway 1983).

These characteristics have been emphasised in the IUCN/SSG Tapir Specialist Group guidelines on reintroduction and translocation, noting that tapirs are highly adaptable to changes in diet, environmental conditions and habitat use and, hence, have the potential to successfully overcome some of the greatest challenges presented to relocated animals. Moreover, tapirs live in ecosystems where biological diversity is maintained, in part, by the tapirs' key ecological roles, including seed predation and dispersal (especially of large seeds), selective sapling browsing in tree fall gaps and nutrient recycling. The guidelines conclude that these important roles make tapirs fundamental components of the restoration of ecosystems and ecological processes (Medici et al. 2008).

Given its recent extermination in Borneo, there appears to be no cultural, environmental, or ecological reason why Malayan tapir could not be reintroduced into suitable protected areas. Translocation could be entirely within national limits and under national legislative control, moving animals within Indonesia from Sumatra to Kalimantan or within Malaysia from a peninsular state to Sarawak or Sabah. The proposal by Piper and Cranbrook (2007) for reintroduction into Borneo under carefully supervised conditions and into 1 or more wellprotected areas of suitable habitat of reasonable extent, is therefore a sound, exciting and feasible prospect. If achieved, such action could be of singular benefit to the conservation of this endangered and vulnerable survivor of the Quaternary megafauna of Southeast Asia.

\section{ACKNOWLEDGEMENTS}

Our thanks to Tong Hauwen and Avinash C. Nanda for generously providing separates of their own work relevant to this paper and for helpful comments on an early draft. Ronald Orenstein kindly read and provided helpful comments on a near final version. Lim Tze Tshen kindly advised on the transliteration of Chinese place names. This review is adapted from a keynote address at the Fifth International Tapir Symposium, IUCN/SSC Tapir Specialist Group, at Hotel Flamingo, Kuala Lumpur, 17 Oct 2011, and a subsequent presentation to the Malayan Nature Society (Sabah Branch) and Sabah So- ciety in Kota Kinabalu, 9 Nov 2011. Lord Cranbrook thanks the organizers of these events for their hospitality and other facilities provided. Many thanks to Ryan Rabett for his continuing collaboration and stimulating insights into the Paleolithic of the region. Philip J. Piper was funded by the ARC Future Fellowship grant FT100100527.

\section{REFERENCES}

Andrews CW (1905). Fossil tooth of Elephas namadicus from Perak. Journal of the Federated Malay States Museums 1, 81-2.

Ansyori MM (2010). Fauna from the oldest occupation layer in Song Terus Cave, Eastern Java, Indonesia (MS thesis). Erasmus Mundus en Quaternaire et Préhistoire, Muséum National d'Histoire Naturelle, Paris.

Arora N, Nater A, van Schaik CP et al. (2010). Effects of Pleistocene glaciations and rivers on the population structure of Bornean orangutans (Pongo pygmaeus). PNAS 107, 21376-81.

Bacon A-M, Demeter F, Duringer P et al. (2008). The Late Pleistocene Duoi U'Oi Cave in northern Vietnam: palaeontology, sedimentology, taphonomy and palaeoenvironments. Quaternary Science Reviews 27, 1627-54.

Bacon A-M, Duringer P, Antoine P-O et al. (2011). The Middle Pleistocene mammalian fauna from Tam Hang karstic deposit, northern Laos: new data and evolutionary hypothesis. Quaternary International 245, 315-32.

Badoux DM (1959). Fossil Mammals from Two Fissure Deposits at Punung (Java). Lingua Terrae Books, Amsterdam, Netherlands.

Barker G, Barton H, Bird M et al. (2007). The 'human revolution' in lowland tropical Southeast Asia: the antiquity and behavior of anatomically modern humans at Niah Cave (Sarawak, Borneo). Journal of Human Evolution 52, 243-61.

Bird M, Taylor D, Hunt C (2005). Palaeoenvironments of insular Southeast Asia during the last glacial period: a savannah corridor in Sundaland? Quaternary Science Review 24, 2228-42.

Bird MI, Boobyer EM, Bryant C, Lewis HA, Paz V, Stephens WE (2007). A long record of environmental change from bat guano deposits in Makangit Cave, Palawan, Philippines. Transactions of the Royal Soci- 
ety of Edinburgh: Earth and Environmental Science 98, 59-69.

Brandon-Jones D (1998). Pre-glacial Bornean primate impoverishment and Wallace's line. In: Hall R, Holloway JD, eds. Biogeography and Geological Evolution of SE Asia. Backhuys Publishers, Leiden, pp. 393-404.

Cannon CH, Morley RJ, Bush ABG (2009). The current refugial rainforests of Sundaland are unrepresentative of their biogeographic past and highly vulnerable to disturbance. PNAS 106, 11188-93.

Chasen FN (1940). A handlist of Malaysian mammals. Bulletin of the Raffles Museum 15, 1-209.

Colbert EH (1943). Pleistocene vertebrates collected in Burma by the American Southeast Asiatic expedition. Transactions of the American Philosophical Society 32, 395- 429.

Corbet GB, Hill JE (1992). The Mammals of the Indomalayan Region: A Systematic Review. Oxford University Press, Oxford.

Corlett RT (2010). Megafaunal extinctions and their consequences in the tropical Indo-Pacific. Terra Australis 32, 117-31.

Cranbrook E of (2004). A history of animal diversity in the Bau limestone area. In: Yong HS, Ng FSP, Yen EEL, eds. Sarawak Bau Limestone Biodiversity. Sarawak Museum Journal 59, 193-220.

Cranbrook E of (2010). Late Quaternary turnover of mammals in Borneo: the zooarchaeological record. Biodiversity and Conservation 19, 373-91.

Cranbrook E of (2013a). Sireh Cave bone in retrospect: bone, teeth and other animal remains from Sarawak Museum excavations of 1954 and 1959. Sarawak Museum Journal (in press).

Cranbrook E of (2013b). The 'Everett collection from Borneo caves' in the Natural History Museum, London: its origin, composition and potential for research. Journal of the Malaysian Branch Royal Asiatic Society (in press).

Cranbrook E of, Piper PJ (2007). The Javan rhinoceros Rhinoceros sondaicus in Borneo. Raffles Bulletin of Zoology 55, 217-20.

Cranbrook E of, Piper PJ (2008). Sarawak through the Ice Ages to present time: environmental change and human impacts on the past and present distribution of mammals. Proceedings of the Regional Conference of Biodiversity Conservation in Tropical Planted Forests in Southeast Asia; 15-18 Jan 2007. Forest De- partment, Sarawak Forestry Corporation, Grand Perfect, Kuching, Sarawak, Malaysia, pp. 81-104.

Cranbrook E of, Piper PJ (2009). Borneo records of Malay tapir Tapirus indicus Desmarest: a zooarchaeological and historical review. International Journal of Osteoarchaeology 19, 491-507.

Cranbrook E of, Payne J, Leh CMU (2007). Origin of the elephants Elephas maximus L. of Borneo. Sarawak Museum Journal 63, 95-125.

Curtis GH, Swisher CC III, Lewin R (2002). Java Man: How Two Geologists Changed our Understanding of Human Evolution. Abacus, Time Warner Books, London, UK.

Darlington PJ Jr (1957). Zoogeography: The Geographical Distribution of Animals. John Wiley and Sons, London.

de Blainville HMD (1839-64). Ostéographie ou Description Iconographique Comparée du Squelette et du Système Dentaire des Mammifères Récents et Fossils, pour servir de base a la zoologie et a la geologie. Livraison 10: Des Viverras. J. P. Baillière, Paris.

Dennell RW (2009). The Palaeolithic Settlement of Asia. Cambridge University Press, Cambridge.

Dennell RW, Roebroeks W (2005). An Asian perspective on early human dispersal from Africa. Nature 438, 1099-104.

de Vos J (1983). The Pongo faunas from Java and Sumatra and their significance for biostratigraphical and palaeo-ecological interpretations. Proceedings Koninklijke Nederlandse Akademie van Wetenschappen Palaeontology B 86, 417-25.

de Vos J (1984). Reconsideration of Pleistocene cave faunas from south China and their relation to the faunas of Java. Courier Forschungsinstitut Senckenberg 69, 259-66.

de Vos J, Sondaar PY (1994). Dating hominid sites in Indonesia. Science 266, 1726-7.

de Vos J, Long VT (2001). First settlements: relations between continental and insular Southeast Asia. In: Sémah F, Falguères C, Grimaud-Hervé D, Sémah AM, eds. Origin of Settlements and Chronology of Palaeolithic Cultures in Southeast Asia. Semenanjung, Paris, pp. 225-49.

Drawhorn GM (1995). Diversity and demography of fossil Pongo. American Journal of Physical Anthropology 20 (Suppl), 85.

Dubois E (1908). Das Geologische Alter der Kendengoder Trinil-Fauna. Brill, Leiden, Netherlands. 
Esselstyn JA, Widmann P, Heaney LR (2004). The mammals of Palawan Island, Philippines. Proceedings of the Biological Society of Washington 117, 271-302.

Flannery T (1994). The Future Eaters: An Ecological History of the Australasian Lands and People. Reed Books, Sydney.

Flannery T (2001). The Eternal Frontier: An Ecological History of North America and its Peoples. William Heinemann, London.

Gani N, Bujeng V, Chia S (2009). Archaeological survey and excavation at Gua Tupak, Bau, Sarawak, a preliminary report. Sarawak Museum Journal 66, 185-97.

Groves C, Grubb P (2011). Ungulate Taxonomy. The Johns Hopkins University Press, Baltimore.

Grubb P (2005). Order Perissodactyla. In: Wilson DE, Reeder DAM, eds. Mammal Species of the World, 3rd edn. The Johns Hopkins University Press, Baltimore.

Heaney LR (1985). Zoogeographic evidence for Middle and Late Pleistocene land bridges to the Philippine islands. Modern Quaternary Research in Southeast Asia 9, 127-44.

Heaney LR (1986). Biogeography of mammals in SE Asia, estimates of rates of colonization, extinction and speciation. Biological Journal of the Linnean Society 28, 127-65.

Hooijer DA (1947). On fossil and prehistoric remains of Tapirus from Java, Sumatra and China. Zoologische Mededeelingen Museum Leiden 27, 253-99.

Hooijer DA (1948). Prehistoric teeth of man and orangutan from central Sumatra, with notes on the fossil orangutan of Java and southern China. Zoologische Mededeelingen Museum Leiden 28, 175-91.

Hooijer DA (1952). Fossil mammals of the Plio-Pleistocene boundary in Java. Proceedings Koninklijke Nederlandse Akademie van Wetenschappen Amsterdam B 55, 436-43.

Hooijer DA (1961). The orangutan in Niah Cave prehistory. Sarawak Museum Journal 9, 408-21.

Hooijer DA (1962a). Report upon a collection of Pleistocene mammals from tin-bearing deposits in a limestone cave near Ipoh, Kinta Valley, Perak. Federation Museums Journal 7, 1-5.

Hooijer DA (1962b). Further 'hell' mammals from Niah. Sarawak Museum Journal 11, 196-200.
Hooijer DA (1962c). Prehistoric bone, the gibbons and monkeys of Niah Great Cave. Sarawak Museum Journal 11, 428-49.

Hooijer DA (1982). Premolars of Elephas planifrons from the Pleistocene of Java. Proceedings Koninklijke Nederlandse Akademie van Wetenschappen B $\mathbf{8 5}$, 265-72.

Johnson C (2006). Australia's Mammal Extinctions: A 50000 Year History. Cambridge University Press, Cambridge, pp. 96-114.

Kahlke HD (1961). On the complex of the StegodonAiluropoda fauna of Southern China and the chronological position of Gigantopithecus blacki v. Koenigswald. Vertebrata PalAsiatica 6, 83-108.

Lekagul B, McNeely JA (1977). Mammals of Thailand. Kurusapha Ladproa Press, Bangkok.

Lewis H, Paz V, Lara M et al. (2008). Terminal Pleistocene to mid-Holocene occupation and an early cremation burial at Ille Cave, Palawan, Philippines. $A n-$ tiquity 82, 318-35.

Locke DP, Hillier DW, Warren WC et al. (2011). Comparative and demographic analysis of orangutan genomes. Nature 469, 529-33.

Long VT, de Vos J, Ciochon RL (1996). The fossil mammal fauna of Lang Trang caves, Vietnam, compared with Southeast Asian fossil and recent mammal faunas: the geographical implications. Bulletin of the Indo-Pacific Prehistory Association 14, 101-9.

Louys J, Curnoe D, Tong H (2007). Characteristics of Pleistocene megafaunal extinctions in Southeast Asia. Palaeogeography, Palaeoclimatology, Palaeoecology 243, 152-73.

Louys J, Meijaard E (2010). Palaeoecology of Southeast Asian megafauna-bearing sites from the Pleistocene and a review of environmental changes in the region. Journal of Biogeography 37, 1432-49.

Lucchini V, Meijaard E, Diong CH, Groves CP, Randi E (2005). New phylogenetic perspectives among species of Southeast Asian wild pig (Sus sp.) based on mtDNA sequences and morphometric data. Journal of the Zoological Society of London 266, 25-35.

Martin PS, Klein RG (1984). Quaternary Extinctions: A Prehistoric Revolution. University of Arizona Press, Tucson.

McLellan B, Reiner DC (1994). A review of bear evolution. A Selection of Papers from the Eighth International Conference on Bear Research and Management 9, 85-96. 
Medici P, Mangini PR, da Silva AG et al. (2008). Guidelines for tapir reintroductions and translocations. IUCN/SSC Tapir Specialist Group (TSG), Gland, Switzerland.

Medway L (1961). The Malay tapir in late Quaternary Borneo. Sarawak Museum Journal 9, 356-60.

Medway L (1972). The Quaternary mammals of Malaysia, a review. In: Ashton PS, Ashton HM, eds. Transactions of the Second Aberdeen-Hull Symposium on Malesian Ecology. Department of Geography, Miscellaneous Series 13, pp. 63-83.

Medway L (1977). Mammals of Borneo: Field Keys and an Annotated Checklist. Monographs of the Malaysian Branch of the Royal Asiatic Society, No. 7, Kuala Lumpur.

Medway L (1983). The Wild Mammals of Malaya (Peninsular Malaysia) and Singapore, 2nd edn. Oxford University Press, Kuala Lumpur.

Mohd Khan MK (1997). Status and action plan of the Malayan tapir (Tapirus indicus). In: Brooks DM, Bodmer RE, Matola S, eds. Tapirs: Status Survey and Conservation Action Plan. IUCN/SSC Tapir Specialist Group, Gland, Switzerland. [Cited 3 Jan 2012.] Available from URL: www.tapirback.com/tapirgal/ iucn-ssc/tsg/action97

Morwood MJ, Sutikna T, Saptomo EW et al. (2008). Climate, people and faunal succession on Java, Indonesia: evidence from Song Gupuh. Journal of Archaeological Science 35, 1776-89.

Nanda AC (2002). Upper Siwalik mammalian faunas of India and associated events. Journal of Asian Earth Sciences 21, 47-58.

Norton CJ, Jin C, Wang Y, Zhang Y (2010). Rethinking the Palearctic-Oriental biogeographic boundary in Quaternary China. In: Norton CJ, Braun DR, eds. Asian Paleoanthropology: From Africa to China and Beyond. Springer, New York, pp. 81-90.

Ochoa J (2008). Terrestrial vertebrates from Ille Cave, northern Palawan, Philippines: Subsistence and palaeoecology in the terminal Pleistocene to the Holocene (MA thesis). University of the Philippines, Quezon City.

Ochoa J, Piper PJ (2013). Holocene large mammal extinctions in Palawan Island, Philippines. In: Monks $\mathrm{G}$, ed. Climate Change, Human Response and Zooarchaeology. Vertebrate Paleobiology and Paleoanthropology Series, Springer, New York (in press).
Patnaik R, Nanda AC (2010). Early Pleistocene mammalian faunas of India and evidence of connections with other parts of the world. In: Fleagle JG, Shea JJ, Grine FE, Baden AL, Leakey RE, eds. Out of Africa I: The First Hominin Colonization of Eurasia. Springer Science, pp. 129-43.

Payne J, Prudente C (2008). Orangutans: Behaviour, Ecology and Conservation. New Holland Publishers Ltd, London.

Piper PJ, Cranbrook E of (2007). The potential of large protected plantation areas for the secure reintroduction Borneo's lost 'megafauna', a case for the Malay tapir Tapirus indicus. Regional Conference of Biodiversity Conservation in Tropical Planted Forests in Southeast Asia; 15-18 Jan 2007. Natural History Publications (Borneo), Kota Kinabalu, pp. 182-9.

Piper PJ, Ochoa J (2007). The first zooarchaeological evidence for the endemic Palawan stink badger (Mydaus marchei Huet 1887). Hukay 11, 85-92.

Piper PJ, Rabett RJ (2009). Hunting in a tropical rainforest: evidence from the terminal Pleistocene at Lobang Hangus, Niah caves, Sarawak. International Journal of Osteoarchaeology 19, 551-65.

Piper PJ, Rabett RJ (2013). The vertebrate fauna. In: Barker G, Gilbertson D, Reynolds T, eds. Rainforest Foraging and Farming in Island Southeast Asia: The Archaeology and Environmental History of the Niah Caves, Sarawak. McDonald Institute Monographs.

Piper PJ, Rabett RJ, Cranbrook E of (2007a). New discoveries of an extinct giant pangolin (Manis cf. palaeojavanica Dubois) at Niah Cave, Sarawak, Borneo: biogeography, paleoecology and taxonomic relationships. Sarawak Museum Journal 63, 205-26.

Piper PJ, Cranbrook E of, Rabett RJ (2007b). Confirmation of the presence of the tiger Panthera tigris (L.) in Late Pleistocene and Holocene Borneo. Malayan Nature Journal 59, 257-65.

Piper PJ, Ochoa J, Lewis H, Paz V, Ronquillo WP (2008). The first evidence for the past presence of the tiger Panthera tigris (L.) on the island of Palawan, Philippines: extinction of the island population. Palaeogeography, Palaeoclimatology, Palaeoecology 264, $123-7$.

Piper PJ, Ochoa J, Robles EC, Lewis H, Paz V (2011). Palaeozoology of Palawan Island, Philippines. Quaternary International 233, 142-58.

Rink WJ, Wei W, Bekken D, Jones HL (2008). Geochronology of Ailuropoda-Stegodon fauna and Giganto- 
pithecus in Guanxi province, southern China. Quaternary Research 69, 377-87.

Romer AS (1966). Vertebrate Palaeontology, 3rd edn. University of Chicago Press, Chicago.

Schwartz JH, Long VT, Cuong NL, Kha LT, Tattersall I (1995). Pleistocene hominoid fauna of the Socialist Republic of Vietnam (excluding Hylobatidae). $A n$ thropological Papers of the American Museum of Natural History 76, 1-24.

Smythies BE (1960). The Birds of Borneo. Oliver and Boyd, Edinburgh.

Storm P (2001). The evolution of humans in Australasia from an environmental perspective. Palaeogeography, Palaeoclimatology, Palaeoecology 171, 363-83.

Storm P, Aziz F, de Vos J et al. (2005). Late Pleistocene Homo sapiens in a tropical rainforest fauna in East Java. Journal of Human Evolution 49, 536-45.

Swisher CC III, Rink WJ, Antón SC, Schwarcz HP, Curtis GH, Suprijo Widiasmoro A (1996). Latest Homo erectus of Java: potential contemporaneity with Homo sapiens in Southeast Asia. Science 274, 1870-74.

Thien ZMM, Htike T, Tsubamoto T, Takai M, Egi N, Maung-Maung (2006). Early Pleistocene Javan rhinoceros from the Irrawaddy Formation, Myanmar. Asian Palaeoprimatology 4, 197-204.

Thien ZMM, Takai M, Tsubamoto T et al. (2010). A review of fossil rhinoceroses from the Neogene of Burma with description of new specimens from the Irrawaddy Sediments. Journal of Asian Earth Sciences 37, 154-65.

Thinh VN, Mootnick AR, Geissman T et al. (2010). Mitichondrial evidence for multiple radiations in the evolutionary history of small apes. BMC Evolutionary Biology 10, 74-87.

Tong H (2005). Dental characters of the Quaternary tapirs in China, their significance in classification and phylogenetic assessment. Geobios 38, 139-50.

Tong H, Guéurin C (2009). Early Pleistocene Dicerorhinus sumatrensis from the Liucheng Gigantipithecus Cave, Guangxi, China. Geobios 42, 525-9.

Tong H, Liu J, Han L (2002). On fossil remains of Early Pleistocene tapir (Perissodactyla, Mammalia) from Fanching, Anhui. Chinese Science Bulletin 47, 58690.

Tong H, Liu J (2004). The Pleistocene-Holocene extinctions of mammals in China. In: Wei D, ed. Proceedings of the Ninth Annual Symposium of the Chinese Society of Vertebrate. Palaeontology China Ocean
Press, Beijing, pp. 111-9 (In Chinese with English summary).

Tong H, Xu F (2001). The origin and evolution of Quaternary tapirs in China. In: Deng T, Wang Y, eds. Proceedings of the Eighth Annual Meeting of the Chinese Society of Vertebrate Palaeontology. China Ocean Press. Beijing, pp. 133-41 (In Chinese with English summary).

Tougard C (1998). Les faunes de grandes mammifères du Pléistocène moyen terminal de Thaïlande dans leur cadre phylogénétique, paléoécologique et biochronologique (PhD dissertation). Université de Montpellier II Sciences et Techniques du Languedoc, Montpellier.

Tun Yin (1967). Wild Animals of Burma. Rangoon Gazette Ltd., Rangoon.

van den Bergh GD, de Vos J, Sondaar PY (2001). The Late Quaternary palaeogeography of mammal evolution in the Indonesian archipelago. Palaeogeography, Palaeoclimatology, Palaeoecology 171, 385-408.

van den Bergh GD, Meijer HJ, Due Awe R et al. (2009). The Liang Bua faunal remains: a 95 kyr sequence from Flores, East Indonesia. Journal of Human Evolution 57, 527-37.

van der Kaars WA, Dam MAC (1995). A 135 000-year record of vegetational and climatic change from the Bandung area, West Java, Indonesia. Palaeogeography, Palaeoclimatology, Palaeoecology 117, 55-72.

Verstappen HT (1975). On palaeo climates and landform development in Malesia. In: Bartstra G, Casparie WA, eds. Modern Quaternary Research in Southeast Asia. A. A. Balkema, Rotterdam, pp. 3-35.

Westaway MC (2002). Preliminary observations on the taphonomic processes at Ngandong and some implications for a late Homo erectus survivor model. Tempus 7, 189-93.

Westaway KE, Morwood MJ, Roberts RG et al. (2007). Age and biostratigraphic significance of the Punung rainforest fauna, east Java, Indonesia and implications for Pongo and Homo. Journal of Human Evolution 53, 709-17.

Wich SA, Meijaard E, Marshall AJ et al. (2008). Distribution and conservation status of the orangutan (Pongo spp.) on Borneo and Sumatra, how many remain? Oryx 42, 329-39.

Williams KD (1978a). Aspects of the ecology and behaviour of the Malayan tapir (Tapirus indicus Des- 
marest) in the National Park of West Malaysia (MSc thesis). Michigan State University, East Lansing, MI.

Williams KD (1978b). Radio-tracking tapirs in the primary rainforest of West Malaysia. Malayan Nature Journal 32, 253-8.

Wong KM (2011). A biogeographic history of Southeast Asian rainforests. In: Wicknesari $\mathrm{R}$, Cannon $\mathrm{C}$, eds. Managing the Future of Southeast Asia's Valuable Tropical Rainforests. A Practitioner's Guide to Forest Genetics. Springer Science + Business Media B. V., Dordrecht, pp. 21-55.

Woodruff D (2010). Biogeography and conservation in Southeast Asia: how 2.7 million years of repeated environmental fluctuations affect today's patterns and the future of the remaining refugial-phase biodiversity. Biodiversity and Conservation 19, 919-41.

Wurster CM, Bird MI, Bull ID et al. (2010). Forest contraction in north equatorial Southeast Asia during the Last Glacial Period. PNAS 107, 15508 -11.

Yasamin Kh. Ibrahim, Lee CP, Cranbrook E of, Lim TT (2010). Vertebrate fossils from Cistern and Swamp caves at Batu caves near Kuala Lumpur, Malaysia. Proceedings of the Geological Society of Malaysia 58, 1-7.

Yasamin Kh. Ibrahim, Lim TT et al. (2013). First discoveries of Pleistocene orangutan (Pongo sp.) fossils in Peninsular Malaysia, biogeographic and palaeoenvironmental implications. Journal of Human Evolution (in press). 